ESTIMATED MONTHLY PERCENTILE DISCHARGES AT UNGAGED

SITES IN THE UPPER YELLOWSTONE RIVER BASIN IN MONTANA

By Charles Parrett and J. A. Hull

U.S. Geological Survey

Water-Resources Investigations Report 86-4009

Prepared in cooperation with the

MONTANA DEPARTMENT OF FISH, WILDLIFE AND PARKS 
UNITED STATES DEPARTMENT OF THE INTERIOR

DONALD PAUL HODEL, Secretary

GEOLOGICAL SURVEY

Dallas L. Peck, Director

For more information

write to:

District Chief

U.S. Geological Survey

428 Federal Building

301 South Park, Drawer 10076

Helena MT 59626-0076
Copies of this report can be purchased from:

Open-File Services Section Western Distribution $\mathrm{Branch}$ U.S. Geological Survey Box 25425, Federal Center Denver C0 80225-0425 
Abstract . . . . . . . . . . . . . . . . . . . . . . 1

Introduction ................................ 1

Description of the study area . . . . . . . . . . . . . . . . . . 2

Description of estimation procedure. . . . . . . . . . . . . . . . . 4

Estimating seasonal mean discharge . . . . . . . . . . . . . . . . . 4

Estimating monthly percentile discharges . . . . . . . . . . . . . . 9

Extending streamflow records to a common base period . . . . . . . . . 15

Reliability of estimation procedure. . . . . . . . . . . . . . . 16

Conclusions. . . . . . . . . . . . . . . . . . . . . . 19

Selected references . . . . . . . . . . . . . . . . . . . 20

\section{ILLUSTRATIONS}

Figure 1. Map showing location of streamflow-measurement sites and streamflow-gaging stations... . . . . . . . . . . . 3

2. Bar graphs comparing dimensionless discharges for each month at selected gaged sites...................... 8

3. Graph showing flow-duration curve of mean April discharge for Big Creek near Emigrant ..................... 10

4. Graphs showing regression equations relating monthly percentile discharge to mean seasonal discharge at nine gaged sites. . . 14

\section{TABLES}

Table 1. Seasonal mean discharge at sites with two flow seasons... . . 6

2. Seasonal mean discharge at sites with three flow seasons . . . . . 7

3. Determination of number of regression equations required . . . . 11

4. Regression constants . . . . . . . . . . . . . . . 12

5. Regression coefficients. . ................13

6. Coefficients of determination $\left(r^{2}\right) . . . . . . . . . . . .13$

7. Estimates of monthly percentile discharge at 1982-83 measurement

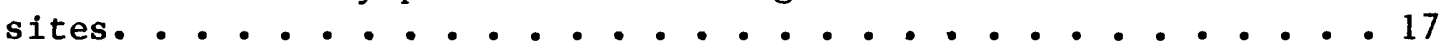

8. Estimates of monthly percentile discharge at 1983-84 measurement sites........................ 17

9. Differences between monthly percentile discharges determined from gage record and regression equations for Mill Creek (site 15). . 18

10. Differences between monthly percentile discharges determined from gage record and regression equations for Brackett Creek (site 33). 18

11. Site descriptions and streamflow measurements .......... 21 


\section{CONVERSION FACTORS}

The following factors can be used to convert inch-pound units in this report to the International System of units (SI).

Multiply inch-pound unit

acre-foot per year

cubic foot per second

$\left(\mathrm{ft}^{3} / \mathrm{s}\right)$

foot ( $f t$ )

inch (in.)

mile (mi)

square mile $\left(\mathrm{mi}^{2}\right)$
By

1,233

0.02832

0.3048

25.40

1.609

2.590
To obtain SI unit

cubic meter per year cubic meter per second

meter

millimeter

kilometer

square kilometer 


\title{
ESTIMATED MONTHLY PERCENTILE DISCHARGES AT UNGAGED SITES IN THE UPPER YELLOWSTONE RIVER BASIN IN MONTANA
}

By Charles Parrett and J. A. Hull

\begin{abstract}
Once-monthly streamflow measurements were used to estimate selected percentile discharges on flow-duration curves of monthly mean discharge for 40 ungaged stream sites in the upper Yellowstone River basin in Montana. The estimation technique was a modification of the concurrent-discharge method previously described and used by H. C. Riggs to estimate annual mean discharge. The modified technique is based on the relationship of various mean seasonal discharges to the required discharges on the flow-duration curves. The mean seasonal discharges are estimated from the monthly streamflow measurements, and the percentile discharges are calculated from regression equations. The regression equations, developed from streamflow record at nine gaging stations, indicated a significant loglinear relationship between mean seasonal discharge and various percentile discharges.
\end{abstract}

The technique was tested at two discontinued streamflow-gaging stations; the differences between estimated monthly discharges and those determined from the discharge record ranged from -31 to +27 percent at one site and from -14 to +85 percent at the other. The estimates at one site were unbiased, and the estimates at the other site were consistently larger than the recorded values. Based on the test results, the probable average error of the technique was \pm 30 percent for the 21 sites measured during the first year of the program and +50 percent for the 19 sites measured during the second year.

\section{INTRODUCTION}

In the early 1970's, Montana citizens became concerned about the possibility of massive water withdrawals for energy development within the Yellowstone River basin. That concern led to the Moratorium on Yellowstone River Appropriations, an act passed by the Montana Legislature in 1973. The moratorium prohibited largescale industrial appropriations until 1977 (later extended to 1978) and, at the same time, allowed political subdivisions to reserve water for future use.

One of the water reservations subsequently granted under provisions of the moratorium was an in-stream reservation for fish and wildlife purposes to the Montana Department of Fish, Wildlife and Parks. On the Yellowstone River mainstem, the reservation was for about 5.5 million acre-feet per year near the point where the river leaves the State, and for lesser amounts at upstream points. For many smaller tributary streams, where little or no streamflow data were available, the reservation was for a specified monthly percentile discharge rather than a specific discharge or volume. Thus, for example, Yellowstone River tributaries upstream from Livingston, Mont., received a 20-percentile discharge reservation for October through April and a 50-percentile discharge reservation for May through September. 
The monthly percentile discharges represent points on the flow-duration curve of mean monthly discharges. The flow-duration curve is a frequency curve that shows the percentage of time a particular mean monthly discharge is exceeded.

For the tributary streams where monthly percentile discharges were reserved, the Montana Department of Fish, Wildlife and Parks was required to develop a plan for quantifying the reserved percentile discharges within 5 years. The department subsequently developed a cooperative study with the U.S. Geological Survey to provide estimates of the required monthly percentile discharges at selected sites in the Yellowstone River basin upstream from Columbus, Mont.

The purposes of this report are to describe the technique used to estimate the monthly percentile discharges and to evaluate the reliability of the results. A 2year project was established to make miscellaneous streamflow measurements at each of the selected sites on a monthly basis from November 1982 through September 1984. About one-half of the sites were measured during the first year of the project, and the rest were measured during the second year, so that 12 measurements were available at each site. The method used to estimate the percentile discharge was a variation of the concurrent-discharge technique used by Riggs (1969) to estimate monthly mean and annual mean discharges at ungaged sites. The reliability of the estimation technique was measured by comparing estimated monthly percentile discharges with those determined from discharge records for two discontinued streamflow-gaging stations.

\section{DESCRIPTION OF THE STUDY AREA}

Twenty-one sites in the Yellowstone River basin upstream from Livingston, Mont., were selected by the Montana Department of Fish, Wildlife and Parks for measurement during the first year of the investigation, and 19 sites between Livingston and Columbus, Mont., were selected for the second year. The basin study area and the location of the 40 measurement sites are shown in figure 1 and the measuring sites are described in table 11 (at the end of the report). Figure 1 also shows the location of 12 streamflow-gaging stations; records for 3 of the stations were used for correlation with the measurement sites and records for 9 of the stations were used in a regression analysis to develop estimating equations for the various monthly percentile discharges.

Twenty of the 21 sites measured the first year are on small streams with drainage areas ranging from 9.77 to $65.8 \mathrm{mi}^{2}$. One site (site 15) is located on a stream with a drainage area of $148 \mathrm{mi}^{2}$. All streams are perennial and drain mountainous areas where the topography is rugged and the mean annual precipitation ranges from about 20 to 40 in. (U.S. Soil Conservation Service, 1977). Four of the sites (sites 13, 19, 20, and 21) have upstream diversions for irrigation; thus, the estimates of monthly percentile discharge for these sites may not be as reliable as estimates made for unregulated sites.

Eighteen of the 19 sites measured during the second year of the program are also on small streams, with drainage areas ranging from 3.88 to $99.8 \mathrm{mi} 2$. One site (site 25) has a drainage area of $217 \mathrm{mi}^{2}$. The second-year measurement sites also are generally located in the mountains, although several sites are located in the foothills where the topography is not as rugged. Mean annual precipitation in the areas measured the second year ranges from about 16 to $40 \mathrm{in.}$, and the climate and streamflow are generally more diverse than in the Yellowstone basin upstream from 


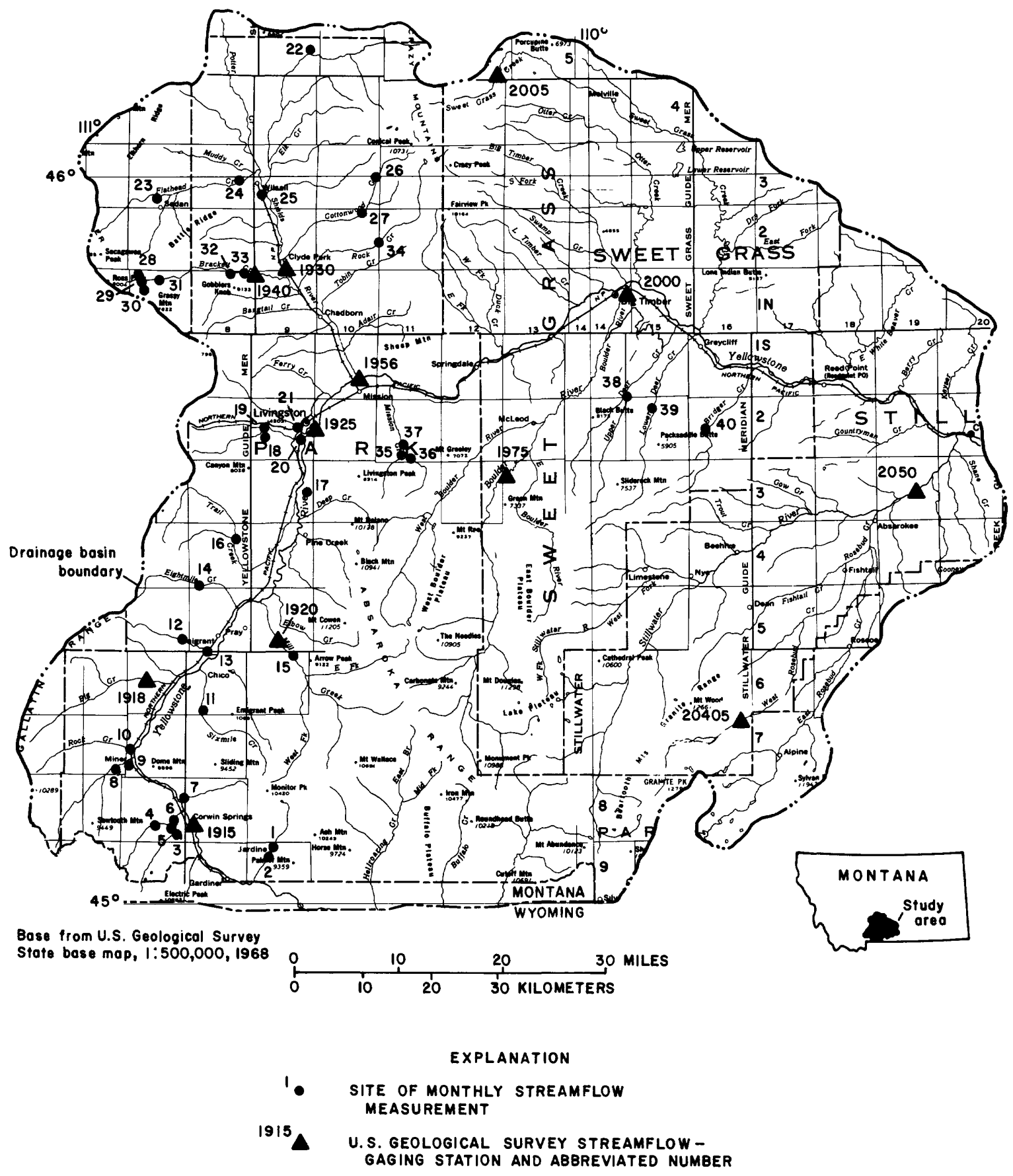

Figure 1.--Location of streamflow-measurement sites and streamflow-gaging stations.

Livingston. Seven of the sites measured the second year have significant upstream diversions for irrigation, and three of these sites are on the same stream (Flathead Creek). Other sites with significant irrigation diversions include Brackett Creek (site 33), Upper and Lower Deer Creeks (sites 38 and 39), and Bridger Creek (site 40). 


\section{DESCRIPTION OF ESTIMATION PROCEDURE}

Riggs (1969) described how once-monthly discharge measurements can be used to estimate monthly mean discharge by assuming that the ratio of the measured discharge to the monthly mean discharge is the same as the ratio determined for a nearby gaged site (correlating site). The monthly mean discharges thus estimated for each month can be summed and averaged to provide an estimate of an annual mean discharge with generally good accuracy ( +10 percent error). The long-term mean annual discharge can be estimated from a regional regression of the annual mean discharge for the measurement year versus the long-term mean annual discharge for several nearby gaged sites. If only one or two nearby gaged sites are available, the long-term mean annual discharge can be estimated from a regional average of the ratios of long-term mean annual discharge to annual mean discharge at the gages. The accuracy of the estimated long-term mean annual discharge is comparable to the accuracy of the estimated annual mean discharge (Riggs, 1969; Parrett and Hu11, 1984).

The individual estimates of monthly mean discharge using the concurrent-discharge technique are generally not accurate. The authors found in a previous study (1984) that estimates of monthly mean discharge were commonly in error by as much as 40-50 percent even when the annual mean flow estimate was within 10 percent of the true value. The primary reason for the greater inaccuracy in estimating a monthly streamflow characteristic is that only one measurement is available for each month for making the estimate, whereas 12 measurements are available for making an estimate of an annual streamflow characteristic. In essence, averaging the individual monthly estimates significantly dampens the individual large errors that may be present in any 1 month. Ideally then, more than one measurement per month is needed to make estimates of monthly streamflow characteristics.

For this study, only one measurement per month was generally available, a1though two measurements were available for some sites during June (table 11). Therefore, the following several-step technique was devised for making the required monthly percentile discharge estimate from several measurements.

\section{Estimating seasonal mean discharge}

The concurrent-discharge technique of Riggs was used to estimate monthly mean discharge for the first year (November 1982 through October 1983) at each of the 21 selected sites upstream from Livingston and for the second year (1984 water year) for the remaining 19 sites (fig. 1). The nearby gaging station used as a correlating site the first year was Big Creek near Emigrant (station 06191800). Gaging stations used as correlating sites the second year were Big Creek near Emigrant and the Shields River near Livingston (station 06195600).

The estimated monthly mean discharges were then summed at each site for various flow seasons. In the study area upstream from Livingston, several different monthly groupings were tried. The grouping that showed the most consistent relationship between the monthly mean discharge and the seasonal mean discharge consisted of two seasons. Thus, a summer season (June through September) corresponds generally to the period of snowmelt runoff from the high-elevation mountains of the upper Yellowstone River basin. Likewise, the remaining months constitute a general1y low-flow season for streams upstream from Livingston. Three sites downstream from Livingston (sites 26, 27, and 34) also were identified as having a two-season pattern of streamflow. 
For the rest of the study area, three distinct seasons of streamflow were identified and used: A high-flow period from April through June, a 3-month period of generally low flow during the irrigation season from July through September, and a generally natural low-flow period from october through March. Where the three seasons were used, the two different low-flow seasons (July-September and OctoberMarch) were generally markedly different from each other. In general, the streams having significant upstream irrigation diversions had similar flows during the two low-flow seasons, whereas the streams without significant irrigation had significantly lower flows from October through March. The seasonal mean discharges determined for the measurement year at each site are given in tables 1 and 2 .

Long-term mean seasonal discharges were determined by applying the average of the ratios of long-term mean seasonal discharge to measurement-year seasonal mean discharge at selected, concurrent gage sites. For the measurement year November 1982 through October 1983, the two gaged sites used to calculate the ratios were Big Creek near Emigrant, the correlating site, and Yellowstone River at Corwin Springs (station 06191500). Thus, for example, the long-term mean seasonal discharge for the high-flow season for Big Creek is $106 \mathrm{ft}^{3} / \mathrm{s}$, and the ratio of the long-term mean seasonal discharge to the measurement year seasonal mean discharge is 1.03. Similarly, the ratio of the long-term mean seasonal discharge to the measurement year high-flow seasonal mean discharge for the Yellowstone River at Corwin Springs is 1.01 , and the average of the two ratios is 1.02 .

For the second measurement year (1984 water year), concurrent gaged sites used to calculate the ratios of long-term mean seasonal discharge to measurement-year seasonal mean discharge were Big Creek, Yellowstone River at Corwin Springs, Ye1lowstone River at Livingston (station 06192500), and Boulder River at Big Timber (station 06200000). The second correlating site, Shields River near Livingston, was not used to calculate the ratios because of its short (6-year) length of record. For the high-flow season (April-June), the average ratio calculated from the four gage sites was 1.04. Similarly for the irrigation season (July-September), the average ratio was 0.97 , and for the low-flow season (October-March) it was 0.77 . The same four concurrent gaged sites were used to calculate an average ratio of long-term mean seasonal discharge to measurement-year seasonal mean discharge for the two-season case (summer season June-September, and low-flow season October-May) so that long-term mean seasonal discharge could be determined for the Cottonwood Creek measurement sites (sites 26 and 27) and for the Rock Creek measurement site (site 34). In this case, the average ratio calculated for each season was 1.10 . The seasonal mean discharges and long-term mean seasonal discharges thus estimated for each measurement site are given in tables 1 and 2 .

To help further explain the reason for using mean seasonal discharges to estimate monthly percentile discharges, three graphs showing the relationships among mean monthly discharge, mean seasonal discharge, and a mid-monthly daily mean discharge or discharge measurement are shown in figure 2. The three graphs are for currently operating gaged sites on the Yellowstone River at Corwin Springs (station 06191500) and Big Creek near Emigrant (station 06191800), and for the discontinued gaged site on Brackett Creek near Clyde Park (station 06194000). As mentioned previously, Big Creek was used as a correlating site for all sites measured during the first year of the program. Brackett Creek was measured once-monthly during the 1984 water year and was used to test the results of the monthly percentile discharge estimating procedure. Data from all three sites were used to develop equations for estimating monthly percentile discharge. All discharges shown on the graphs for the three sites are dimensionless discharges that were derived by 


\begin{tabular}{|c|c|c|c|c|c|}
\hline \multirow[b]{2}{*}{$\begin{array}{l}\text { Site } \\
\text { No. }\end{array}$} & \multirow[b]{2}{*}{ Stream name } & \multicolumn{2}{|c|}{$\begin{array}{c}\text { Seasonal mean } \\
\text { discharge, in } \\
\text { cubic feet per } \\
\text { second, for 1982-83 } \\
\text { measurement year }\end{array}$} & \multicolumn{2}{|c|}{$\begin{array}{c}\text { Long-term mean } \\
\text { seasonal discharge, } \\
\text { in cubic feet } \\
\text { per second }\end{array}$} \\
\hline & & $\begin{array}{l}\text { Summer } \\
\text { season } \\
\text { (June- } \\
\text { Sept.) }\end{array}$ & $\begin{array}{l}\text { Low-f low } \\
\text { season } \\
\text { (Oct.- } \\
\text { May) }\end{array}$ & $\begin{array}{l}\text { Summer } \\
\text { season } \\
\text { (June- } \\
\text { Sept.) }\end{array}$ & $\begin{array}{l}\text { Low-f low } \\
\text { season } \\
\text { (Oct.- } \\
\text { May) }\end{array}$ \\
\hline 1 & $\begin{array}{l}\text { Bear Creek above North Fork Bear } \\
\text { Creek }\end{array}$ & 79.1 & 13.0 & 80.7 & 14.7 \\
\hline 2 & $\begin{array}{l}\text { Bear Creek below North Fork Bear } \\
\text { Creek }\end{array}$ & 141 & 21.7 & 144 & 24.5 \\
\hline 3 & Mol Heron Creek & 38.0 & 15.5 & 38.8 & 17.5 \\
\hline 4 & $\begin{array}{l}\text { Cinnabar Creek above Cottonwood } \\
\text { Creek }\end{array}$ & 13.9 & 8.12 & 14.2 & 9.18 \\
\hline 5 & Cinnabar Creek at mouth & 15.2 & 10.5 & 15.5 & 11.9 \\
\hline 6 & $\begin{array}{l}\text { Mol Heron Creek below Cinnabar } \\
\text { Creek }\end{array}$ & 52.0 & 21.4 & 53.1 & 24.2 \\
\hline 7 & Cedar Creek at mouth & 11.1 & 7.39 & 11.3 & 8.35 \\
\hline 8 & $\begin{array}{l}\text { Tom Miner Creek above Canyon } \\
\text { Creek }\end{array}$ & 90.5 & 43.6 & 92.3 & 49.3 \\
\hline 9 & Tom Miner Creek at mouth & 79.9 & 41.2 & 81.5 & 46.6 \\
\hline 10 & Rock Creek at mouth & 45.3 & 10.3 & 46.2 & 11.6 \\
\hline 11 & Sixmile Creek & 66.1 & 14.9 & 67.4 & 16.8 \\
\hline 12 & Fridley Creek above Miller Creek & 28.1 & 13.9 & 28.7 & 15.7 \\
\hline 13 & Fridley Creek at mouth & 11.5 & 4.16 & 11.7 & 4.70 \\
\hline 14 & Eightmile Creek & 25.4 & 22.5 & 25.9 & 25.4 \\
\hline 15 & Mill Creek above diversions & 313 & 68.5 & 319 & 77.4 \\
\hline 16 & Trail Creek & 23.6 & 17.5 & 24.1 & 19.8 \\
\hline 17 & Suce Creek & 13.4 & 2.34 & 13.7 & 2.64 \\
\hline 18 & Billman Creek above Miner Creek & 8.23 & 12.1 & 8.39 & 13.7 \\
\hline 19 & Miner Creek & 4.89 & 9.56 & 4.99 & 10.8 \\
\hline 20 & Billman Creek at mouth & 10.7 & 20.9 & 10.9 & 23.6 \\
\hline 21 & Fleshman Creek at mouth & 2.34 & 6.74 & 2.39 & 7.62 \\
\hline 26 & $\begin{array}{l}\text { Cottonwood Creek above Slippery } \\
\text { Creek }\end{array}$ & ${ }^{1} 53.4$ & ${ }^{\mathrm{l}} 18.8$ & 48.6 & 17.1 \\
\hline 27 & $\begin{array}{l}\text { Cottonwood Creek below Little } \\
\text { Cottonwood Creek }\end{array}$ & 143.9 & ${ }^{1} 26.4$ & 39.9 & 24.0 \\
\hline 34 & Rock Creek & ${ }^{1} 61.9$ & ${ }^{1} 19.8$ & 56.3 & 18.0 \\
\hline
\end{tabular}

${ }^{1}$ Seasonal mean discharges determined from measurements in 1983-84. 
Table 2.--Seasonal mean discharge at sites with three flow seasons

\begin{tabular}{|c|c|c|c|c|c|c|c|}
\hline \multirow[b]{2}{*}{$\begin{array}{l}\text { Site } \\
\text { No. }\end{array}$} & \multirow[b]{2}{*}{ Stream name } & \multicolumn{3}{|c|}{$\begin{array}{c}\text { Seasonal mean } \\
\text { discharge, in cubic } \\
\text { feet per second, } \\
\text { for } 1983-84 \\
\text { measurement year }\end{array}$} & \multicolumn{3}{|c|}{$\begin{array}{l}\text { Long-term mean } \\
\text { seasonal discharge, } \\
\text { in cubic feet per second } \\
\end{array}$} \\
\hline & & $\begin{array}{l}\text { High- } \\
\text { flow } \\
\text { season } \\
\text { (Apr.- } \\
\text { June) }\end{array}$ & $\begin{array}{l}\text { Irri- } \\
\text { gation } \\
\text { season } \\
\text { (July- } \\
\text { Sept.) }\end{array}$ & $\begin{array}{l}\text { Low- } \\
\text { flow } \\
\text { season } \\
\text { (Oct.- } \\
\text { Mar.) }\end{array}$ & $\begin{array}{l}\text { High- } \\
\text { flow } \\
\text { season } \\
\text { (Apr.- } \\
\text { June) }\end{array}$ & $\begin{array}{l}\text { Irri- } \\
\text { gation } \\
\text { season } \\
\text { (July- } \\
\text { Sept.) }\end{array}$ & $\begin{array}{l}\text { Low- } \\
\text { flow } \\
\text { season } \\
\text { (Oct.- } \\
\text { Mar.) }\end{array}$ \\
\hline 22 & Smith Creek & 69.9 & 9.51 & 4.46 & 72.7 & 9.22 & 3.43 \\
\hline 23 & $\begin{array}{l}\text { Flathead Creek above } \\
\text { Cache Creek }\end{array}$ & 33.9 & 9.38 & 7.17 & 35.3 & 9.10 & 5.52 \\
\hline 24 & $\begin{array}{l}\text { Flathead Creek above } \\
\text { Muddy Creek }\end{array}$ & 94.6 & 23.7 & 22.8 & 98.4 & 23.0 & 17.6 \\
\hline 25 & $\begin{array}{l}\text { Flathead Creek at } \\
\text { mouth }\end{array}$ & 104 & 17.5 & 32.1 & 108 & 17.0 & 24.7 \\
\hline 28 & $\begin{array}{l}\text { North Fork Brackett } \\
\text { Creek }\end{array}$ & 31.1 & 7.94 & 3.56 & 32.3 & 7.70 & 2.74 \\
\hline 29 & $\begin{array}{l}\text { Middle Fork Brackett } \\
\text { Creek }\end{array}$ & 26.8 & 3.36 & 2.19 & 27.9 & 3.26 & 1.69 \\
\hline 30 & $\begin{array}{l}\text { South Fork Brackett } \\
\text { Creek }\end{array}$ & $20 \cdot 4$ & $4 \cdot 10$ & 1.66 & 21.2 & 3.98 & 1.28 \\
\hline 31 & $\begin{array}{l}\text { Brackett Creek above } \\
\text { Weasel Creek }\end{array}$ & 82.1 & 15.6 & 7.11 & 85.4 & 15.1 & 5.47 \\
\hline 32 & $\begin{array}{l}\text { Brackett Creek above } \\
\text { Fox Creek }\end{array}$ & 120 & $21 \cdot 3$ & 12.8 & 125 & 20.7 & 9.86 \\
\hline 33 & $\begin{array}{l}\text { Brackett Creek near } \\
\text { mouth (old gaged } \\
\text { site) }\end{array}$ & 125 & 19.5 & $15 \cdot 5$ & 130 & 18.9 & 11.9 \\
\hline 35 & $\begin{array}{l}\text { Mission Creek above } \\
\text { Little Mission } \\
\text { Creek }\end{array}$ & 47.9 & 26.4 & 8.19 & 49.8 & 25.6 & 6.31 \\
\hline 36 & Little Mission Creek & 24.3 & 6.79 & 3.41 & 25.3 & 6.59 & 2.63 \\
\hline 37 & $\begin{array}{l}\text { Mission Creek below } \\
\text { Little Mission } \\
\text { Creek }\end{array}$ & 72.2 & 33.2 & 11.6 & 75.1 & 32.2 & 8.93 \\
\hline $\begin{array}{l}38 \\
39 \\
40\end{array}$ & $\begin{array}{l}\text { Upper Deer Creek } \\
\text { Lower Deer Creek } \\
\text { Bridger Creek }\end{array}$ & $\begin{array}{l}99.0 \\
76.7 \\
33.4\end{array}$ & $\begin{array}{c}8.69 \\
16.6 \\
4.18\end{array}$ & $\begin{array}{l}7.33 \\
7.40 \\
3.71\end{array}$ & $\begin{array}{r}103 \\
79.8 \\
34.7\end{array}$ & $\begin{array}{c}8.43 \\
16.1 \\
4.05\end{array}$ & $\begin{array}{l}5.64 \\
5.70 \\
2.86\end{array}$ \\
\hline
\end{tabular}




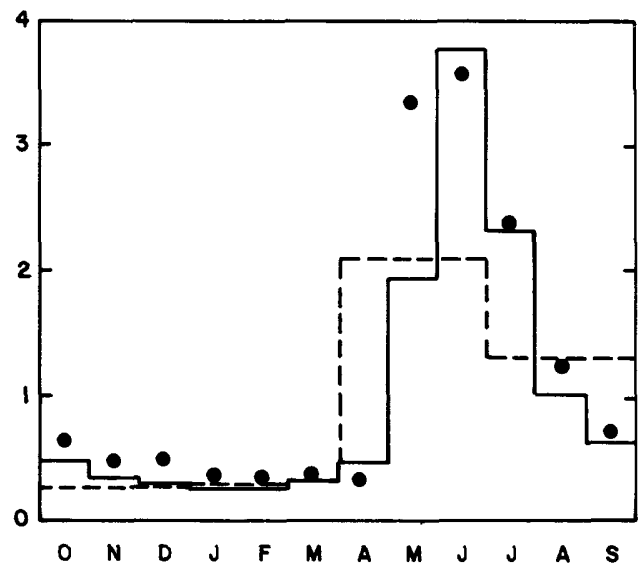

A. Yellowstone River of Corwin Springs (stotion 06191500 ) Drainage oreo $=2623$ square miles

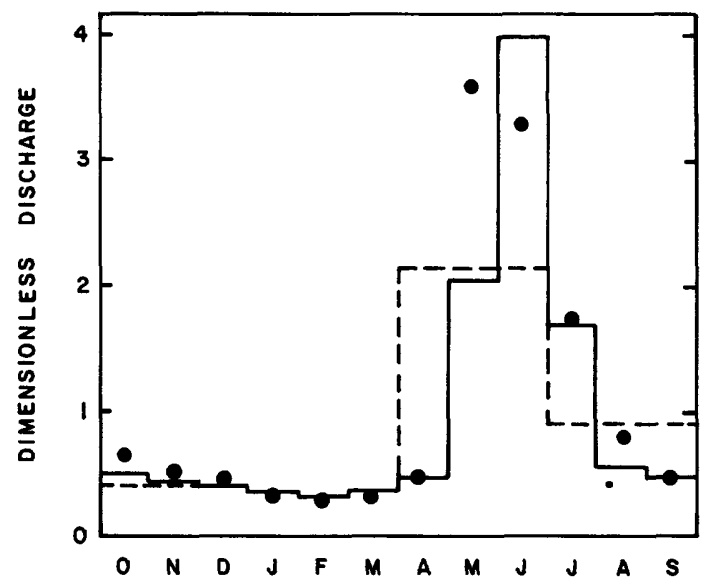

EXPLANATION

LONG-TERM MEAN MONTHLY DISCHARGE

LONG-TERM MEAN SEASONAL DISCHARGE

- MID-MONTHLY DAILY MEAN DISCHARGE

IN $1984--$ Measured discharge for Brackett Creek

8. Big Creek near Emigrant (station 06191800) Drainage area $=60.9$ square miles

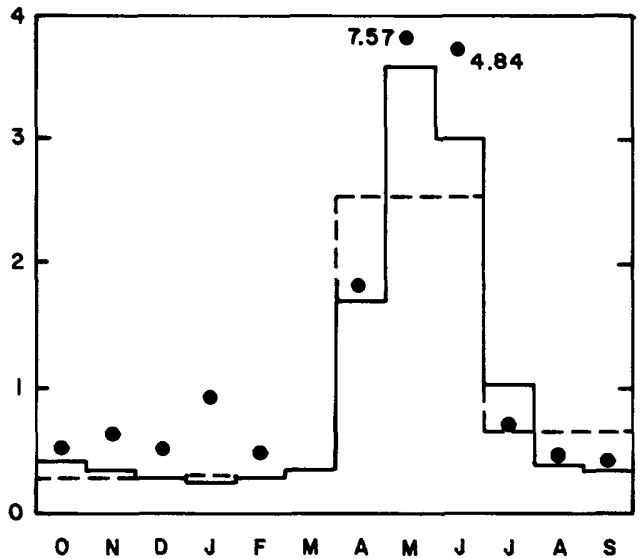

C. Brockett Creek near Clyde Park (station 06194000 ) Drainoge area $=57.9$ equare miles

Figure 2.--Bar graphs comparing dimensionless discharges for each month at selected gaged sites. 
dividing each discharge value by the long-term mean annual discharge for each site. Each graph is thus directly comparable to the others even though the drainage areas and actual mean discharges are greatly different at each site.

Comparison of the bar graphs for the Yellowstone River and Big Creek indicates that the runoff patterns for the two streams are remarkably similar, even though there are large differences in size of drainage area. The mean monthly dimensionless discharges for July, August, and September and the corresponding irrigationseason mean seasonal dimensionless discharge for the Yellowstone River are slightly larger than those for Big Creek, indicating the greater lake storage in the Yellowstone River basin. The bar graph for Brackett Creek shows that runoff begins earlier in this stream basin than in Big Creek or the Yellowstone River, and that the mean monthly discharges during the high-flow season (April through June) are more consistent than in the other two basins. Because Brackett Creek is farther downstream than the other two sites, Brackett Creek is believed to be more generally representative of the ungaged measurement sites downstream from Livingston.

As indicated by all three bar graphs, the mid-monthly daily mean discharge is often significantly different from the mean monthly discharge, particularly during months of high flow. Of particular interest is the fact that the mid-monthly discharge is significantly larger than the mean monthly discharge for May at the Yellowstone River and Big Creek sites, but is significantly smaller than the mean monthly discharge for June at the same two sites. For these sites, it is thus apparent that using a seasonal average of three mid-monthly discharges for April, May, and June would result in better estimates of the mean monthly discharges for those 3 months than would using just the individual mid-monthly daily mean discharges.

For the Brackett Creek site, however, each of the three mid-monthly discharges is greater than the mean monthly discharge for April, May, and June. Using the average of the three mid-monthly discharges thus would not result in improved estimates for the mean monthly discharges overall, but the estimate for the month with the largest difference between mid-monthly and mean monthly discharge (June) would be improved.

Because of the often large differences in measured discharge from month to month at many of the ungaged measurement sites, averaging of monthly mean discharge estimates to produce seasonal mean discharge estimates is believed to result in overall improvement of the monthly percentile discharge estimates. As shown by the bar graph for Brackett Creek, however, the improvement of estimates due to averaging may be negligible at some sites.

\section{Estimating monthly percentile discharges}

The flow-duration curve of mean monthly discharges can be used to show monthly percentile discharges. For example, the 20-percentile discharge for April is the discharge exceeded, on the average, by the mean monthly discharge in April for 2 years of every 10. An example flow-duration curve for mean monthly discharge in April for Big Creek near Emigrant is shown in figure 3. In this instance, the 20percentile discharge is $57.0 \mathrm{ft}^{3} / \mathrm{s}$. On the average, the monthly mean discharge during April for Big Creek near Emigrant will be greater than $57.0 \mathrm{ft}^{3} / \mathrm{s}$ only 20 -percent of the time (2 years of every 10$)$. 


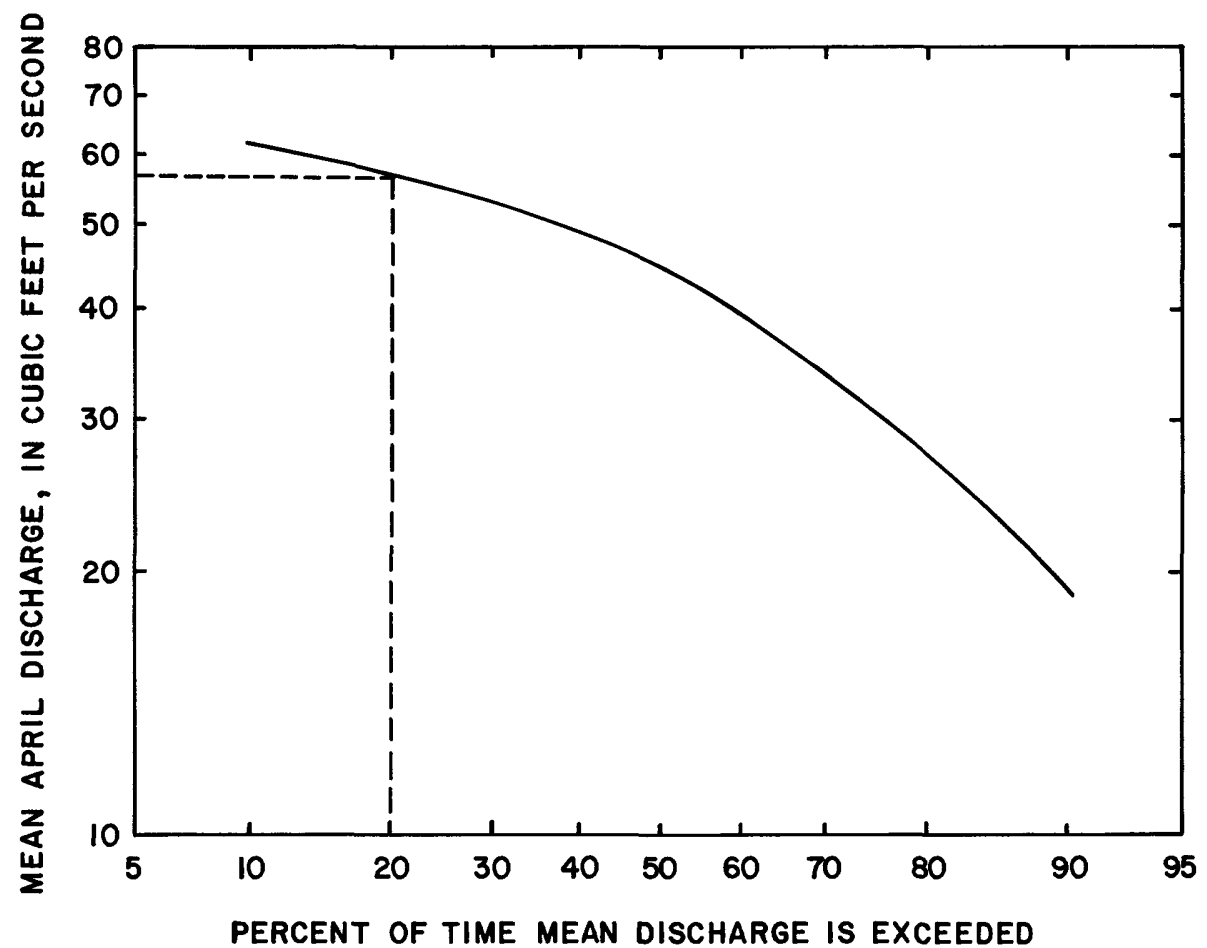

Figure 3.--Flow-duration curve of mean April discharge for Big Creek near Emigrant.

To obtain a relationship between the long-term mean seasonal discharges and the required long-term monthly percentile discharges, data from nine gaging stations were used, including one of the stations used as a correlating site for the determination of the seasonal mean discharges. Four of the stations used for the regression analyses were on streams with some upstream diversions for irrigation.

The streamflow-gaging-station data were used to develop regression equations relating the desired monthly percentile discharge to the appropriate long-term mean seasonal discharge. Because two different patterns of seasonal means were used (two seasons upstream from Livingston, three seasons for most sites downstream) and because the required monthly percentiles varied from site to site, more than 12 separate regression equations were required. The required monthly percentile and the number of seasons used to determine seasonal mean discharge (independent variable) for each month for each of the 40 measurement sites are given in table 3 . Thus, 43 separate regression equations were needed to provide all the required monthly percentiles.

The regression equations developed for each month were of the following loglinear form:

$$
\begin{gathered}
\log Q_{p}=\log \mathrm{a}+\mathrm{b} \log Q_{S} \\
\text { or } \\
Q_{p}=\mathrm{a} Q_{S}{ }^{\mathrm{b}}
\end{gathered}
$$


where

$Q_{p}$ is the monthly percentile discharge for a particular month,

$a$ is the linear regression constant,

$b$ is the regression coefficient, and

$Q_{S}$ is the long-term mean seasonal discharge corresponding to the particular month.

For example, the regression equation developed for estimating the required percentile discharge for December for sites 1 through 21 was:

$$
Q_{20}=0.38 Q_{S}^{1.09}
$$

where

$Q_{S}$ is the long-term mean seasonal discharge computed for October through May. Likewise, the regression equation developed for estimating the required percentile discharge for May for sites 38 through 40 was:

$$
Q_{90}=1.20 Q_{S}^{0.86}
$$

where

$Q_{S}$ is the long-term mean seasonal discharge computed for April through June.

\begin{tabular}{|c|c|c|c|}
\hline $\begin{array}{l}\text { Site } \\
\text { Nos. }\end{array}$ & $\frac{\text { Percentiles required }}{\text { October-April }}$ & $\begin{array}{c}\text { for specified months } \\
\text { May-September }\end{array}$ & $\begin{array}{c}\text { Number of seasons } \\
\text { used to calculate } \\
\text { seasonal means }\end{array}$ \\
\hline $\begin{array}{ll}1-21 & \\
26-27 ; 34 \\
22-25 ; 28-33 \\
35-37 \\
38-40\end{array}$ & $\left.\begin{array}{c}20 \\
50 \\
50 \\
50 \\
90\end{array}\right\}=$ & $\left.\begin{array}{l}50 \\
50 \\
50 \\
90 \\
90\end{array}\right\} 1$ & $\begin{array}{l}2 \\
2 \\
3 \\
3 \\
3\end{array}$ \\
\hline $\begin{array}{l}\text { Number of } \\
\text { regressions } \\
\text { required = }\end{array}$ & 7 months $\times 4=28$ & 5 months $\times 3=15$ & \\
\hline
\end{tabular}

Table 3.--Determination of number of regression equations required

1 Percentiles and number of seasons are the same; one set of equations required. 
Because only nine gaged sites were used in the regression analyses, the regression lines were graphically fitted to the nine data points rather than using a mathematical, least-squares fitting procedure. The graphical fitting allowed some subjective weighting of the data points when one or two gaged sites were thought to be more hydrologically similar to the measurement sites where the percentile discharge estimates were required. For example, when fitting regression lines for the estimation of percentile discharges for sites measured the first year, more weight was usually given to the Big Creek gaged site (station 06191800) because it is more like measurement sites 1 through 21 than any of the other gaged sites. Likewise, when fitting regression lines for the estimation of percentile discharges for sites measured the second year, more weight was usually given to the Big Creek or Shields River (station 06193000) gaged site.

Regression constants, regression coefficients, and coefficients of determination $\left(r^{2}\right)$ were computed for each of the 43 graphical regressions (tables 4-6). The regression constants range from 0.17 to 4.49 , with the largest values for any given percentile occurring in May or June. The regression coefficients range from 0.86 to 1.14 , indicating that the relationship between the various percentile discharges and the mean seasonal discharges is almost linear (coefficient $=1.00$ ) for all 43 equations. The coefficients of determination range from 0.927 to 0.999 , indicating that the regression lines fit the data points with only a small degree of scatter in all instances.

For purposes of illustration, three of the graphical regressions are shown in figure 4. The regression line relating the 50-percentile discharge for April to the mean seasonal discharge for April through June (three-season pattern) is shown in figure 4A. This regression had the smallest coefficient of determination and consequently the greatest scatter about the regression line. As indicated by figure $4 \mathrm{~A}$, the regression line closely fits the nine data points regardless of the

Table 4.--Regression constants

\begin{tabular}{|c|c|c|c|c|}
\hline \multirow[b]{2}{*}{ Month } & \multicolumn{2}{|c|}{$\begin{array}{l}\text { Three-season pattern for } \\
\text { indicated percentile required }\end{array}$} & \multicolumn{2}{|c|}{$\begin{array}{l}\text { Two-season pattern for } \\
\text { indicated percentile required }\end{array}$} \\
\hline & 50 & 90 & 50 & 20 \\
\hline January & 0.76 & 0.48 & 0.22 & 0.28 \\
\hline February & .76 & .48 & .22 & .25 \\
\hline March & 1.00 & .51 & .23 & .32 \\
\hline April & .60 & .17 & .99 & 1.59 \\
\hline May & 1.65 & 1.20 & 4.49 & -- \\
\hline June & .57 & 1.26 & 2.87 & -- \\
\hline July & 1.35 & .85 & .60 & -- \\
\hline August & .51 & .22 & .17 & -- \\
\hline September & .53 & .25 & .21 & -- \\
\hline October & 1.20 & .61 & .38 & .52 \\
\hline November & .98 & .86 & .35 & .52 \\
\hline December & .85 & .58 & .26 & .38 \\
\hline
\end{tabular}


Table 5.--Regression coefficients

\begin{tabular}{|c|c|c|c|c|}
\hline \multirow[b]{2}{*}{ Month } & \multicolumn{2}{|c|}{$\begin{array}{l}\text { Three-season pattern } \\
\text { for indicated per- } \\
\text { centile required }\end{array}$} & \multicolumn{2}{|c|}{$\begin{array}{l}\text { Two-season pattern } \\
\text { for indicated per- } \\
\text { centile required } \\
\end{array}$} \\
\hline & 50 & 90 & 50 & 20 \\
\hline January & 1.00 & 1.07 & 1.13 & 1.12 \\
\hline February & 1.00 & 1.07 & 1.13 & 1.14 \\
\hline March & .97 & 1.04 & 1.13 & 1.10 \\
\hline April & .86 & .94 & .96 & .94 \\
\hline May & .92 & .86 & .94 & -- \\
\hline June & 1.14 & 1.00 & .95 & -- \\
\hline July & 1.04 & 1.00 & 1.09 & -- \\
\hline August & 1.04 & 1.09 & 1.13 & -- \\
\hline September & .98 & 1.00 & 1.05 & -- \\
\hline October & 1.01 & 1.12 & 1.13 & 1.11 \\
\hline November & 1.03 & 1.00 & 1.11 & 1.08 \\
\hline December & 1.02 & 1.05 & .99 & 1.09 \\
\hline
\end{tabular}

Table 6.--Coefficients of determination $\left(r^{2}\right)$

\begin{tabular}{|c|c|c|c|c|}
\hline \multirow[b]{2}{*}{ Month } & \multicolumn{2}{|c|}{$\begin{array}{l}\text { Three-season pattern } \\
\text { for indicated per- } \\
\text { centile required }\end{array}$} & \multicolumn{2}{|c|}{$\begin{array}{l}\text { Two-season pattern } \\
\text { for indicated per- } \\
\text { centile required } \\
\end{array}$} \\
\hline & 50 & 90 & 50 & 20 \\
\hline January & 0.999 & 0.995 & 0.989 & 0.991 \\
\hline February & .998 & .996 & .991 & .991 \\
\hline March & .994 & .994 & .988 & .986 \\
\hline April & .927 & .952 & .965 & .956 \\
\hline May & .995 & .987 & .990 & -- \\
\hline June & .992 & .982 & .998 & -- \\
\hline $\mathrm{July}$ & .999 & .996 & .997 & -- \\
\hline August & .999 & .998 & .994 & -- \\
\hline September & .995 & .996 & .989 & -- \\
\hline October & .999 & .996 & .988 & .990 \\
\hline November & .998 & .998 & .989 & .993 \\
\hline December & .999 & .997 & .989 & .994 \\
\hline
\end{tabular}




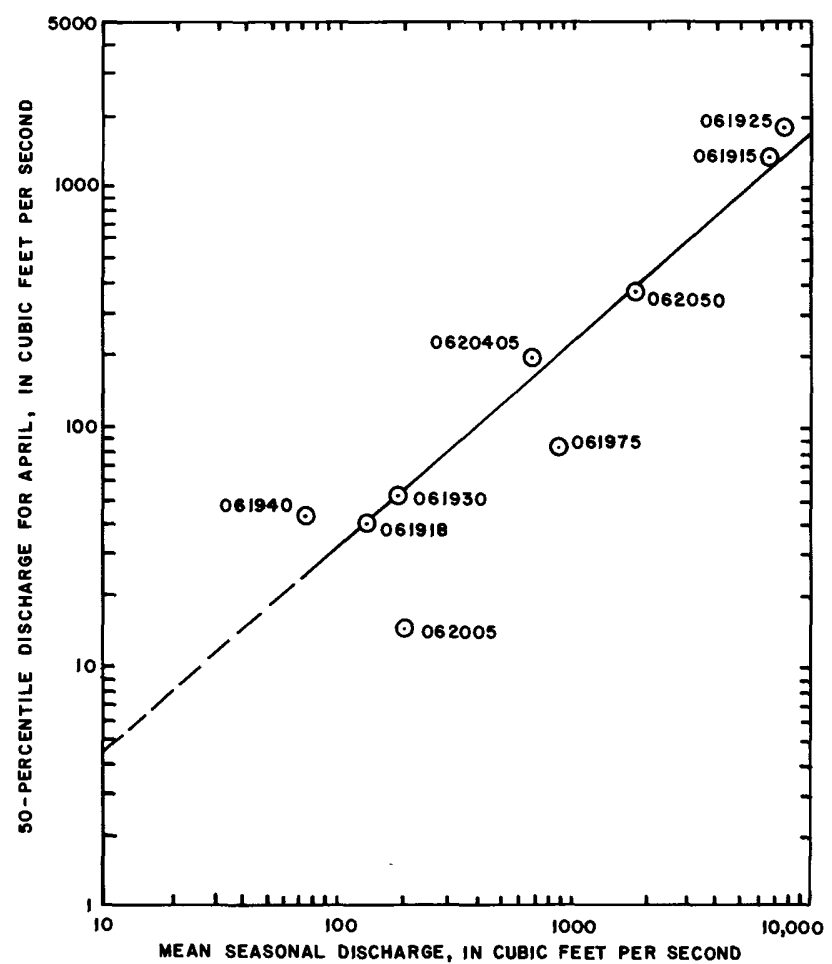

A. High-flow season April through June (three-season pattern)

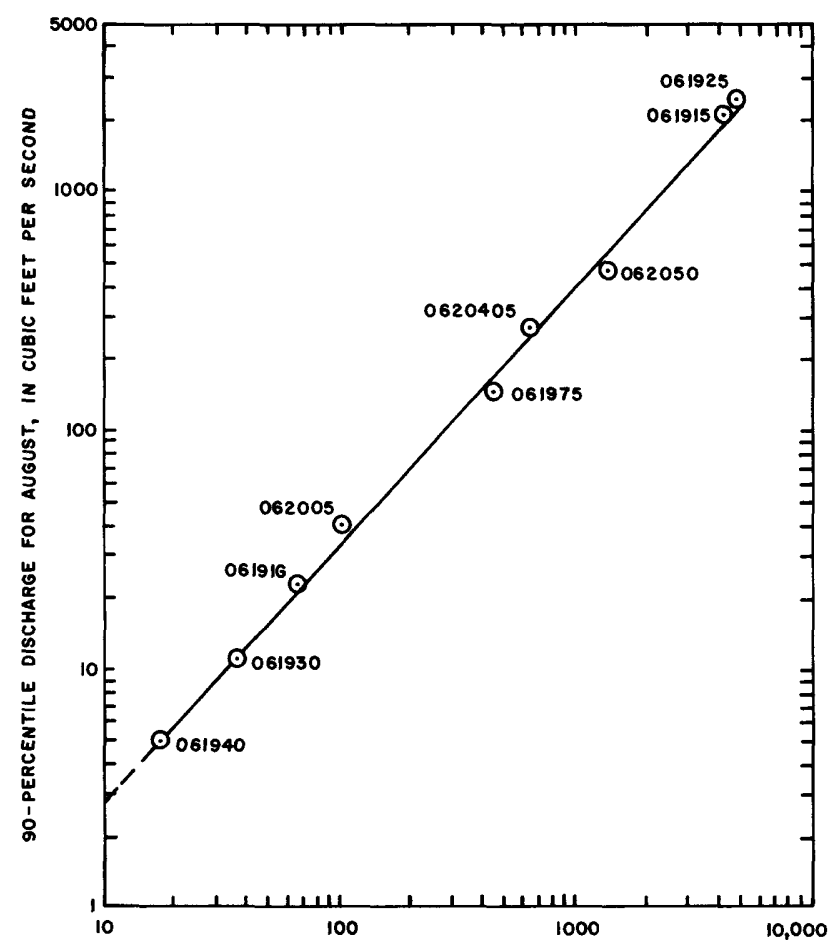

MEAN SEASONAL DISCHARGE, IN CUBIC FEET PER SECOND B. Low - flow season July through September (three-sooson pattern)

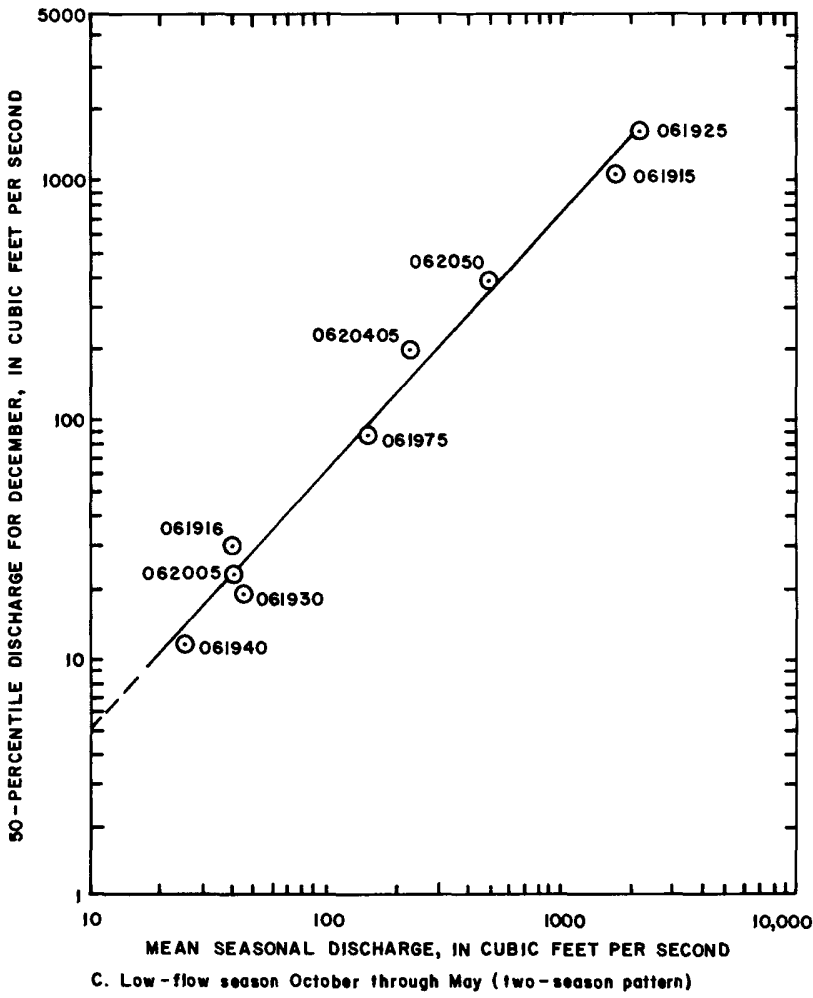

C. Low - flow season October through May (iwo-seeson pattorn)

Figure 4.--Regression equations relating monthly percentile discharge to mean seasonal discharge at nine gaged sites. 
relatively small coefficient of determination. The regression line relating the 90-percentile discharge for August to the mean seasonal discharge for July through September (three-season pattern) is shown in figure 4B. This regression illustrates the scatter about the regression line for a month when irrigation is most significant. The regression line relating the 50-percentile discharge for December to the mean seasonal discharge for October through May is shown in figure 4C. This graph illustrates the scatter about the regression line for a typical low-flow month where a two-season mean discharge was used. As before, the fit to the nine data points is generally very good.

\section{Extending streamflow records to a common base period}

The monthly percentile discharges for the nine gaged sites used in the regression analyses were obtained from flow-duration curves of mean monthly discharge for each month. The number of points used to develop each flow-duration curve is equal to the number of years of record at the site. In general, the more data points (years of record) used to draw the flow-duration curve, the more reliable the curve. Also, a flow-duration curve based on a short record may reflect short-term hydrologic conditions that are not representative of long-term, future conditions. Accordingly, a procedure for extending short-term streamflow records to a longer, common base period was used.

The method chosen to extend streamflow records was a statistical regression procedure developed by the U.S. Army Corps of Engineers (1971). The regression procedure (HEC-4) uses monthly flow data from several streamflow gages in an area to estimate missing monthly flow values for each gage and for each year of record. The method also preserves the variance of the unadjusted short-term record by adding a random component to the estimated values. Starting with the first year of data, missing monthly streamflows are estimated at all stations for each month in sequence. Thus, when a missing flow is being estimated, there is always a valid value for all stations already examined that month and for all remaining stations in either the current or the preceding month. The equation for estimating missing flows has the following general form:

$$
\begin{aligned}
Q_{i, j}= & B_{1} Q_{i, 1}+\ldots+B_{j-1} Q_{i, j-1}+B_{j} Q_{i-1, j} \\
& +B_{j+1} Q_{i, j+1}+\ldots+B_{n} Q_{i, n}+\sqrt{1-R^{2}{ }_{i, j}}\left(Z_{i, j}\right),
\end{aligned}
$$

where

$Q_{i, j}$ is the monthly flow logarithm, expressed as a standard normal deviate, for month $i$ and station $j$,

$B_{j}$ is the beta coefficient for station $j$ computed from a correlation matrix of flows at all $n$ stations,

$R_{i, j}$ is the multiple correlation coefficient for month $i$ and station $j$, and

$z_{i, j}$ is a random number generated from a standard normal population.

If any station being used to estimate a missing monthly flow is also missing a flow value for that month ( $i)$, then the flow for the preceding month $(i-l)$ is used in the right side of equation 5. If, for example, the monthly flow at station 1 and month $i$ were missing, the first term on the right side of equation 5 would be $B_{1} Q_{i-1, l}$. 
For this study, the HEC-4 procedure was used to develop a common base period for nine gaged sites used in the regression analyses. The earliest year that any two of the nine gages had record was 1934. Consequently, 1934 was the first year of the common base period, and the HEC- 4 procedure was used to extend all shortterm gage record through 1982. The monthly percentile discharges at each site were thus taken from flow-duration curves developed from the common 1934-82 base period.

\section{RELIABILITY OF ESTIMATION PROCEDURE}

Regardless of the generally good fit to the data points, estimates of monthly percentile discharge were required for sites with smaller discharges than any of the gaged sites. Thus, the regression equations had to be used to make estimates outside the range of data used to derive the equations, and the results may be questionable. Accordingly, two measurement sites where some streamflow record was available were used to make an independent evaluation of the predictive reliability of the regression equations.

The 43 regression equations developed from the gaging-station data were used to estimate the various monthly percentile discharges required at the 40 selected sites (tables 7 and 8 ). One of the first-year measurement sites (Mill Creek, site 15) was located about 2 miles upstream from a discontinued streamflow-gaging station (Mill Creek near Pray, site 06192000). Although no significant tributaries occur between the gage and the measurement site, several large ditches divert irrigation water during the irrigation season. Streamflow at the two sites thus is not equivalent during the irrigation season but is considered to be equivalent during the rest of the year. The monthly percentile discharges estimated at the measurement site, therefore, can be compared to the monthly percentile discharges determined from the record for the non-irrigation season. As indicated in table 9, the differences between the estimated percentile discharges and those determined from the record range from -31 percent to +27 percent, with the average monthly difference being +3 percent. The estimated discharges were larger than those from the record for 5 months, and the discharges from the record were larger than those estimated for 4 months. No strong bias in the estimation technique thus is indicated for the Mill Creek site.

Although using one gaged site as a test site is not a rigorous test of the accuracy of the estimation technique, the Mill Creek gaged site is believed to be hydrologically similar to the other 20 sites measured the first year. Also, the expected error of the estimated monthly percentile discharges for those 20 sites probably is comparable to the differences found for Mill Creek (about \pm 30 percent).

One of the sites measured during the second year of the program (site 33) is also the site of a discontinued streamflow-gaging station (Brackett Creek near Clyde Park, 06194000). For this site, the estimated monthly percentile discharges could be compared to percentile discharges from the record for all 12 months (table 10). The differences between estimated values and values from the record ranged from -14 percent to +85 percent, with the average monthly difference being +28 percent. The estimation procedure consistently overestimated monthly percentile discharges for Brackett Creek for 10 of the 12 months, evidently because the measured flows during the 1984 water year were substantially larger than mean flows based on the record. Because other gaged sites used for correlation purposes did not indicate such a large difference between 1984 streamflow and record-based mean flows, the bias toward large estimates on Brackett Creek would not necessarily apply to 
Table 7.--Estimates of monthly percentile discharge at 1982-83 measurement sites

Percentile discharge for month indicated, in cubic feet per second

20 percent 50 percent

\begin{tabular}{|c|c|c|c|c|c|c|c|c|c|c|c|c|c|}
\hline \multirow{2}{*}{$\begin{array}{l}\text { Site } \\
\text { No. }\end{array}$} & \multirow[b]{2}{*}{ Stream } & \multicolumn{4}{|c|}{20 percent } & \multicolumn{5}{|c|}{50 percent } & \multicolumn{3}{|c|}{20 percent } \\
\hline & & JAN & FEB & MAR & APR & MAY & JUNE & JULY & AUG & SEPT & OCT & NOV & DEC \\
\hline 1 & $\begin{array}{l}\text { Bear Creek above North Fork } \\
\text { Bear Creek }\end{array}$ & 5.68 & 5.35 & 6.15 & 19.9 & 56.2 & 186 & 71.9 & 24.3 & 21.1 & 10.3 & 9.48 & 7.11 \\
\hline 2 & $\begin{array}{l}\text { Bear Creek below North Fork } \\
\text { Bear Creek }\end{array}$ & 10.1 & 9.58 & 10.8 & 32.2 & 90.8 & 322 & 135 & 46.7 & 38.8 & 18.1 & 16.5 & 12.4 \\
\hline $\begin{array}{l}3 \\
4\end{array}$ & $\begin{array}{l}\text { Mo } 1 \text { Heron Creek } \\
\text { Cinnabar Creek above } \\
\text { Cottonwood Creek }\end{array}$ & $\begin{array}{l}6.91 \\
3.35\end{array}$ & $\begin{array}{l}6.53 \\
3.13\end{array}$ & $\begin{array}{l}7.46 \\
3.67\end{array}$ & $\begin{array}{l}23.4 \\
12.8\end{array}$ & $\begin{array}{l}66.2 \\
36.1\end{array}$ & $\begin{array}{l}92.7 \\
35.7\end{array}$ & $\begin{array}{l}32.4 \\
10.8\end{array}$ & $\begin{array}{l}10.6 \\
3.41\end{array}$ & $\begin{array}{l}9.78 \\
3.41\end{array}$ & $\begin{array}{l}12.5 \\
6.09\end{array}$ & $\begin{array}{l}11.4 \\
5.70\end{array}$ & $\begin{array}{l}8.60 \\
4.26\end{array}$ \\
\hline 5 & Cinnabar Creek at mouth & 4.29 & 4.21 & 4.88 & 16.3 & 46.1 & 38.8 & 11.9 & 3.76 & 3.73 & 8.13 & 7.54 & 5.65 \\
\hline 6 & $\begin{array}{l}\text { Mol Heron Creek below } \\
\text { Cinnabar Creek }\end{array}$ & 9.93 & 9.45 & 10.6 & 31.8 & 89.7 & 125 & 45.6 & 15.1 & 13.6 & 17.9 & 16.2 & 12.3 \\
\hline $\begin{array}{l}7 \\
8\end{array}$ & $\begin{array}{l}\text { Cedar Creek at mouth } \\
\text { Tom Miner Creek above } \\
\text { Canyon Creek }\end{array}$ & $\begin{array}{l}3.02 \\
22.0\end{array}$ & 21.81 & 23.30 & $\begin{array}{l}11.7 \\
62.0\end{array}$ & 175 & 211 & $\begin{array}{ll}8.43 \\
83.2\end{array}$ & $\begin{array}{l}2.63 \\
28.3\end{array}$ & $\begin{array}{l}2.68 \\
24.3\end{array}$ & $\begin{array}{l}5.48 \\
39.4\end{array}$ & $\begin{array}{l}5.15 \\
35.0\end{array}$ & $\begin{array}{l}3.84 \\
26.6\end{array}$ \\
\hline $\begin{array}{r}9 \\
10\end{array}$ & $\begin{array}{l}\text { Tom Miner Creek at mouth } \\
\text { Rock Creek at mouth }\end{array}$ & $\begin{array}{r}20.7 \\
4.36\end{array}$ & $\begin{array}{l}19.9 \\
4.09\end{array}$ & $\begin{array}{r}21.9 \\
4.74\end{array}$ & $\begin{array}{l}58.8 \\
15.9\end{array}$ & $\begin{array}{r}166 \\
45.0\end{array}$ & $\begin{array}{l}188 \\
109\end{array}$ & $\begin{array}{l}72.7 \\
39.1\end{array}$ & $\begin{array}{l}24.6 \\
12.9\end{array}$ & $\begin{array}{l}21.3 \\
11.8\end{array}$ & $\begin{array}{r}37.0 \\
7.90\end{array}$ & $\begin{array}{l}33.0 \\
7.34\end{array}$ & $\begin{array}{l}25.0 \\
5.50\end{array}$ \\
\hline $\begin{array}{l}11 \\
12\end{array}$ & $\begin{array}{l}\text { Sixmile Creek } \\
\text { Fridley Creek above } \\
\quad \text { Miller Creek }\end{array}$ & $\begin{array}{l}6.60 \\
6.12\end{array}$ & $\begin{array}{l}6.23 \\
5.77\end{array}$ & $\begin{array}{l}7.13 \\
6.62\end{array}$ & $\begin{array}{l}22.6 \\
21.2\end{array}$ & $\begin{array}{l}63.7 \\
59.8\end{array}$ & $\begin{array}{l}157 \\
69.6\end{array}$ & $\begin{array}{l}59.1 \\
23.3\end{array}$ & $\begin{array}{l}19.8 \\
7.55\end{array}$ & $\begin{array}{r}17.5 \\
7.13\end{array}$ & $\begin{array}{l}11.9 \\
11.1\end{array}$ & $\begin{array}{l}10.9 \\
10.2\end{array}$ & $\begin{array}{l}8.23 \\
7.64\end{array}$ \\
\hline $\begin{array}{l}13 \\
14 \\
15\end{array}$ & $\begin{array}{l}\text { Fridley Creek at mouth } \\
\text { Eightmile Creek } \\
\text { Mill Creek above } \\
\text { diversions }\end{array}$ & $\begin{array}{l}1.58 \\
10.5 \\
36.5\end{array}$ & $\begin{array}{l}1.46 \\
9.99 \\
35.6\end{array}$ & $\begin{array}{l}1.76 \\
11.2 \\
38.3\end{array}$ & $\begin{array}{l}6.81 \\
33.3 \\
94.8\end{array}$ & $\begin{array}{r}19.2 \\
93.9 \\
268\end{array}$ & $\begin{array}{r}29.7 \\
63.2 \\
688\end{array}$ & $\begin{array}{l}8.76 \\
20.8 \\
323\end{array}$ & $\begin{array}{r}2.74 \\
6.72 \\
115\end{array}$ & $\begin{array}{l}2.78 \\
6.40 \\
89.7\end{array}$ & $\begin{array}{l}2.90 \\
18.9 \\
64.9\end{array}$ & $\begin{array}{l}2.77 \\
17.1 \\
57.0\end{array}$ & $\begin{array}{l}2.05 \\
12.9 \\
43.5\end{array}$ \\
\hline $\begin{array}{l}16 \\
17 \\
18\end{array}$ & $\begin{array}{l}\text { Trail Creek } \\
\text { Suce Creek } \\
\text { Billman Creek above } \\
\text { Miner Creek }\end{array}$ & $\begin{array}{r}7.93 \\
.83 \\
5.25\end{array}$ & $\begin{array}{r}7.52 \\
.76 \\
4.94\end{array}$ & $\begin{array}{r}8.54 \\
.93 \\
5.70\end{array}$ & $\begin{array}{l}26.3 \\
3.96 \\
18.6\end{array}$ & $\begin{array}{l}74.3 \\
11.2 \\
52.6\end{array}$ & $\begin{array}{l}59.0 \\
34.5 \\
21.6\end{array}$ & $\begin{array}{l}19.3 \\
10.4 \\
6.10\end{array}$ & $\begin{array}{l}6.20 \\
3.27 \\
1.88\end{array}$ & $\begin{array}{l}5.93 \\
3.28 \\
1.96\end{array}$ & $\begin{array}{r}14.3 \\
1.53 \\
9.50\end{array}$ & $\begin{array}{r}13.1 \\
1.48 \\
8.78\end{array}$ & $\begin{array}{l}9.84 \\
1.09 \\
6.59\end{array}$ \\
\hline $\begin{array}{l}19 \\
20\end{array}$ & $\begin{array}{l}\text { Miner Creek } \\
\text { Billman Creek at mouth }\end{array}$ & $\begin{array}{l}4.02 \\
9.66\end{array}$ & $\begin{array}{l}3.77 \\
9.18\end{array}$ & $\begin{array}{l}4.38 \\
10.4\end{array}$ & $\begin{array}{l}14.9 \\
31.0\end{array}$ & $\begin{array}{l}42.0 \\
87.7\end{array}$ & $\begin{array}{l}13.2 \\
27.8\end{array}$ & $\begin{array}{l}3.46 \\
8.11\end{array}$ & $\begin{array}{l}1.05 \\
2.53\end{array}$ & $\begin{array}{l}1.14 \\
2.58\end{array}$ & $\begin{array}{l}7.30 \\
17.4\end{array}$ & $\begin{array}{l}6.79 \\
15.8\end{array}$ & $\begin{aligned} & 5.08 \\
& 11.9\end{aligned}$ \\
\hline 21 & Fleshman Creek at mouth & 2.72 & 2.53 & 2.99 & 10.7 & 30.3 & 6.57 & 1.55 & .46 & .52 & 4.95 & 4.66 & 3.48 \\
\hline
\end{tabular}

Table 8.--Estimates of monthly percentile discharge at 1983-84 measurement sites

Percentile discharge ${ }^{1}$ for month indicated, in cubic feet per second

\begin{tabular}{|c|c|c|c|c|c|c|c|c|c|c|c|c|c|}
\hline \multirow{2}{*}{$\begin{array}{l}\text { Site } \\
\text { No. }\end{array}$} & \multirow[b]{2}{*}{ Stream } & & & & & & & & & & & & \\
\hline & & JAN & FEB & MAR & APR & MAY & JUNE & JULY & AUG & SEPT & OCT & NOV & DEC \\
\hline $\begin{array}{l}22 \\
23\end{array}$ & $\begin{array}{l}\text { Smith Creek } \\
\text { Flathead Creek above } \\
\text { Cache Creek }\end{array}$ & $\begin{array}{l}2.61 \\
4.20\end{array}$ & $\begin{array}{l}2.61 \\
4.20\end{array}$ & $\begin{array}{l}3.31 \\
5.24\end{array}$ & $\begin{array}{l}23.9 \\
12.9\end{array}$ & $\begin{array}{l}85.1 \\
43.8\end{array}$ & $\begin{array}{l}75.5 \\
33.1\end{array}$ & & $\begin{array}{l}5.14 \\
5.07\end{array}$ & $\begin{array}{l}4.67 \\
4.61\end{array}$ & & $\begin{array}{l}3.49 \\
5.69\end{array}$ & $\begin{array}{l}2.99 \\
4.86\end{array}$ \\
\hline 24 & $\begin{array}{l}\text { Flathead Creek above } \\
\text { Muddy Creek }\end{array}$ & 13.4 & 13.4 & 16.1 & 31.1 & 112 & 107 & 35.2 & 13.3 & 11.4 & 21.7 & 18.8 & $15 \cdot 8$ \\
\hline $\begin{array}{l}25 \\
26\end{array}$ & $\begin{array}{l}\text { Flathead Creek at mouth } \\
\text { Cottonwood Creek above } \\
\text { Slippery Creek }\end{array}$ & $\begin{array}{l}18.8 \\
5.44\end{array}$ & $\begin{array}{l}18.8 \\
5.44\end{array}$ & $\begin{array}{l}22.4 \\
5.69\end{array}$ & $\begin{array}{l}33.6 \\
15.1\end{array}$ & $\begin{array}{r}123 \\
74.8\end{array}$ & $\begin{array}{l}119 \\
105\end{array}$ & $\begin{array}{l}25.7 \\
41.4\end{array}$ & $\begin{array}{r}9.71 \\
13.7\end{array}$ & $\begin{array}{l}8.51 \\
12.4\end{array}$ & $\begin{array}{r}30.6 \\
9.40\end{array}$ & $\begin{array}{r}26.7 \\
8.18\end{array}$ & $\begin{array}{r}22.4 \\
6.43\end{array}$ \\
\hline 27 & $\begin{array}{l}\text { Cottonwood Creek below } \\
\text { Little Cottonwood Creek }\end{array}$ & 7.98 & 7.98 & 8.34 & 20.9 & 79.8 & 105 & 33.3 & 11.0 & 10.1 & 13.8 & 11.9 & 9.43 \\
\hline $\begin{array}{l}28 \\
29 \\
30 \\
31\end{array}$ & $\begin{array}{l}\text { North Fork Brackett Creek } \\
\text { Middle Fork Brackett Creek } \\
\text { South Fork Brackett Creek } \\
\text { Brackett Creek above } \\
\text { Weasel Creek }\end{array}$ & $\begin{array}{r}2.08 \\
1.28 \\
.97 \\
4.16\end{array}$ & $\begin{array}{r}2.08 \\
1.28 \\
.97 \\
4.16\end{array}$ & $\begin{array}{l}2.66 \\
1.66 \\
1.27 \\
5.20\end{array}$ & $\begin{array}{l}11.9 \\
10.5 \\
8.29 \\
27.5\end{array}$ & $\begin{array}{l}40.4 \\
35.3 \\
27.4 \\
98.7\end{array}$ & $\begin{array}{l}29.9 \\
25.3 \\
18.5 \\
90.7\end{array}$ & $\begin{array}{l}11.3 \\
4.61 \\
5.68 \\
22.7\end{array}$ & $\begin{array}{l}4.26 \\
1.74 \\
2.15 \\
8.58\end{array}$ & $\begin{array}{l}3.92 \\
1.69 \\
2.05 \\
7.58\end{array}$ & $\begin{array}{l}3.32 \\
2.04 \\
1.54 \\
6.68\end{array}$ & $\begin{array}{l}2.77 \\
1.68 \\
1.26 \\
5.64\end{array}$ & $\begin{array}{l}2.38 \\
1.45 \\
1.09 \\
4.81\end{array}$ \\
\hline 32 & $\begin{array}{l}\text { Brackett Creek above } \\
\text { Fox Creek }\end{array}$ & 7.49 & 7.49 & 9.21 & 38.1 & 140 & 140 & & & & & 10.3 & 8.77 \\
\hline 33 & $\begin{array}{l}\text { Brackett Creek near mouth } \\
\text { (old gaged site) }\end{array}$ & 9.04 & 9.04 & 11.0 & 39.5 & 145 & 146 & 28.7 & 10.8 & 9.45 & 14.6 & 12.6 & 10.6 \\
\hline 34 & $\begin{array}{l}\text { Rock Creek below Little } \\
\text { Rock Creek }\end{array}$ & 5.77 & 5.77 & 6.03 & 15.9 & 68.0 & 132 & 48.6 & 16.2 & 14.5 & 9.96 & 8.66 & 6.81 \\
\hline 35 & $\begin{array}{l}\text { Mission Creek above Little } \\
\text { Mission Creek }\end{array}$ & 4.80 & 4.80 & 5.97 & 17.3 & 278.6 & 262.7 & 221.8 & 27.54 & 26.40 & 7.71 & 6.54 & 5.56 \\
\hline 36 & Little Mission Creek & 2.00 & 2.00 & 2.55 & 9.66 & 238.1 & 231.9 & 25.60 & 21.72 & 21.65 & 3.19 & 2.65 & 2.28 \\
\hline 37 & $\begin{array}{l}\text { Mission Creek below Little } \\
\text { Mission Creek }\end{array}$ & 6.79 & 6.79 & 8.36 & 24.6 & 2122 & 294.6 & 227.4 & 29.68 & 28.05 & 11.0 & 9.35 & 7.93 \\
\hline $\begin{array}{l}38 \\
39 \\
40\end{array}$ & $\begin{array}{l}\text { Mission Creek } \\
\text { Upper Deer Creek } \\
\text { Lower Deer Creek } \\
\text { Bridger Creek }\end{array}$ & $\begin{array}{l}23.06 \\
23.09 \\
21.48\end{array}$ & $\begin{array}{l}2.06 \\
23.09 \\
21.48\end{array}$ & $\begin{array}{l}23.08 \\
23.12 \\
21.52\end{array}$ & $\begin{array}{l}213.3 \\
210.4 \\
24.77\end{array}$ & $\begin{array}{l}264.6 \\
251.9 \\
225.3\end{array}$ & $\begin{array}{l}2130 \\
2101 \\
243.7\end{array}$ & $\begin{array}{r}27.17 \\
213.7 \\
23.44\end{array}$ & $\begin{array}{l}22.25 \\
24.55 \\
21.01\end{array}$ & $\begin{array}{l}22.11 \\
24.03 \\
21.01\end{array}$ & $\begin{array}{l}24.23 \\
24.28 \\
21.98\end{array}$ & $\begin{array}{l}24.85 \\
24.90 \\
24.46\end{array}$ & $\begin{array}{l}23.57 \\
23.61 \\
21.75\end{array}$ \\
\hline
\end{tabular}

150 percent for a11 sites, except as indicated.

290 percent. 
Table 9.--Differences between monthly percentile discharges determined from gage record and regression equations for Mill Creek (site 15)

\begin{tabular}{|c|c|c|c|}
\hline \multirow[b]{2}{*}{ Month } & \multicolumn{2}{|c|}{$\begin{array}{l}\text { Percentile discharge for month } \\
\text { indicated, in cubic feet per second }\end{array}$} & \multirow{2}{*}{$\begin{array}{l}\text { Percent } \\
\text { difference } \\
\text { from } \\
\text { discharge } \\
\text { record }\end{array}$} \\
\hline & $\begin{array}{l}\text { Estimated from } \\
\text { regression } \\
\text { equations }\end{array}$ & $\begin{array}{l}\text { Determined from } \\
\text { discharge record }\end{array}$ & \\
\hline January & 36.5 & 33.0 & +11 \\
\hline February & 35.6 & 34.0 & +5 \\
\hline March & 38.3 & 33.0 & +16 \\
\hline April & 94.8 & 80.0 & +19 \\
\hline May & 268 & 388 & -31 \\
\hline June & 688 & 757 & -9 \\
\hline July & 323 & - & -- \\
\hline August & 115 & -- & -- \\
\hline September & 89.7 & -- & -- \\
\hline October & 64.9 & 51.0 & +27 \\
\hline November & 57.0 & 58.0 & -2 \\
\hline December & 43.5 & 47.0 & -8 \\
\hline
\end{tabular}

IAverage percent difference $=+3$

Table 10.--Differences between monthly percentile discharges determined from gage record and regression equations

for Brackett Creek (site 33)

\begin{tabular}{|c|c|c|c|}
\hline \multirow[b]{2}{*}{ Month } & \multicolumn{2}{|c|}{$\begin{array}{l}\text { Percentile discharge for month } \\
\text { indicated, in cubic feet per second }\end{array}$} & \multirow{2}{*}{$\begin{array}{l}\text { Percent } \\
\text { difference } \\
\text { from } \\
\text { discharge } \\
\text { record }\end{array}$} \\
\hline & $\begin{array}{l}\text { regression } \\
\text { equations }\end{array}$ & $\begin{array}{l}\text { Determined from } \\
\text { discharge record }\end{array}$ & \\
\hline January & 9.04 & 7.00 & +29 \\
\hline February & 9.04 & 7.00 & +29 \\
\hline March & 11.0 & 9.00 & +22 \\
\hline April & 39.5 & 42.0 & -6 \\
\hline May & 145 & 93.0 & +56 \\
\hline June & 146 & 79.0 & +85 \\
\hline July & 28.7 & 27.0 & +6 \\
\hline August & 10.8 & 10.0 & +8 \\
\hline September & 9.45 & 11.0 & -14 \\
\hline October & 14.6 & 11.0 & +33 \\
\hline November & 12.6 & 9.00 & +40 \\
\hline December & 10.6 & 7.00 & +51 \\
\hline
\end{tabular}

${ }^{1}$ Average percent difference $=+28$ 
the other 18 sites measured in 1984. Thus, the mean of the largest absolute differences between estimated and record-based percentile discharges for Brackett Creek ( +50$)$ probably are comparable to the expected errors of the estimation procedure for the sites measured during 1984. The sites measured during the second year of the program were not as similar as the first-year measurement sites, and the probable error of the estimated monthly percentile discharges is greater for the second-year sites.

It is important to note that the estimates of monthly percentile discharges furnished to the Montana Department of Fish, Wildlife and Parks for the two gaged sites (Mill Creek and Brackett Creek) were based on actual gage data (non-irrigation months only for Mill Creek). In addition, the estimates for the other sites on Brackett Creek were adjusted to reflect the difference between the estimates from the regression equations and the values from the record determined for the gaged site.

To apply the estimation technique described in this report to a different study area, different seasonal mean discharges would probably need to be computed. The season would need to be selected so that the monthly mean discharges for each month comprising the seasons are approximately equal. At the same time, the number of seasons would be limited so that each seasonal mean discharge is based on an average of at least three monthly mean discharge estimates. Having at least three values to average tends to dampen any large individual errors that could be present in any single monthly mean discharge estimate.

\section{CONCLUSIONS}

Monthly percentage discharges were estimated for ungaged sites based on oncemonthly streamflow measurements. The technique used is a modification of the concurrent-discharge technique previously used to estimate annual mean discharge. Several steps were required to use the modified technique.

Based on the results of an application to two discontinued streamflow-gaging stations, the modified technique provides reasonably accurate estimates of monthly percentile discharge at the selected sites. For the 21 sites measured during the first year of the project, the probable average error for any month is within the range of differences found at the Mill Creek test site ( +30 percent). For the sites measured during the second year, the expected average error of the monthly estimates is within the range of differences found at the Brackett Creek test site but without the bias toward overestimation. The mean of the largest absolute differences between estimated and record-based monthly percentile discharges for Brackett Creek ( +50 percent) probably is close to the average error of the monthly estimates made for the sites measured the second year.

The expected errors of monthly percentile discharge estimated for this study are significantly larger than the errors reported by Riggs (1969) and Parrett and Hull (1984) for estimating mean annual discharge. This result is to be expected, however, because an estimate of mean annual discharge is based on an average of 12 separate measurements. An estimate of a monthly streamflow characteristic made using the concurrent-discharge technique is based on only one measurement for that month. Thus, using the concurrent-discharge technique to estimate monthly discharges would provide substantially more accurate estimates only if more measurements per month were made or, better yet, if the measurements were continued for several years. 
The accuracy of the concurrent-discharge technique for estimating either mean annual discharge or monthly percentile discharge also is largely dependent upon having a suitable correlating gaged site. If the correlating gaged site has streamflow characteristics different from those of the ungaged measurement site, the resulting monthly mean discharge estimate will be in error. The seasonal mean discharge or the annual mean discharge subsequently calculated from the individual monthly estimates thus could be subject to a substantial cumulative error. The errors of estimation described above for this study include the errors due to imperfect correlation but, because each study area and its correlating sites are unique, the errors of estimation likely would be different for different study areas.

\section{SELECTED REFERENCES}

Missouri River Basin Commission, 1978, Yellowstone River Basin and adjacent coal area, Level B study, volume 1: Omaha, Nebr., 279 p.

Parrett, Charles, and Hull, J. A., 1984, Streamflow characteristics of mountain streams in western Montana: U.S. Geological Survey Water-Supply Paper 2260, 58 p.

Peterman, Larry, and Nelson, Fred, 1983, The Yellowstone River instream reservation, fifth annual report and five year summary: Helena, Montana Department of Fish, Wildlife and Parks, 51 p.

Riggs, H. C., 1969, Mean streamflow from discharge measurements: International Association of Scientific Hydrology Bulletin 14, p. 95-110.

U.S. Army Corps of Engineers, 1971, HEC-4 monthly streamflow simulation: Hydrologic Engineering Center, 113 p.

U.S. Soil Conservation Service, 1977, Average annual precipitation, Montana, based on 1941-1970 base period: Bozeman, Mont., 13 p. 
Table 11.--Site descriptions and streamflow measurements [ft, foot; $\mathrm{ft}^{3} / \mathrm{s}$, cubic foot per second; $\mathrm{mi}, \mathrm{mile}$ ]

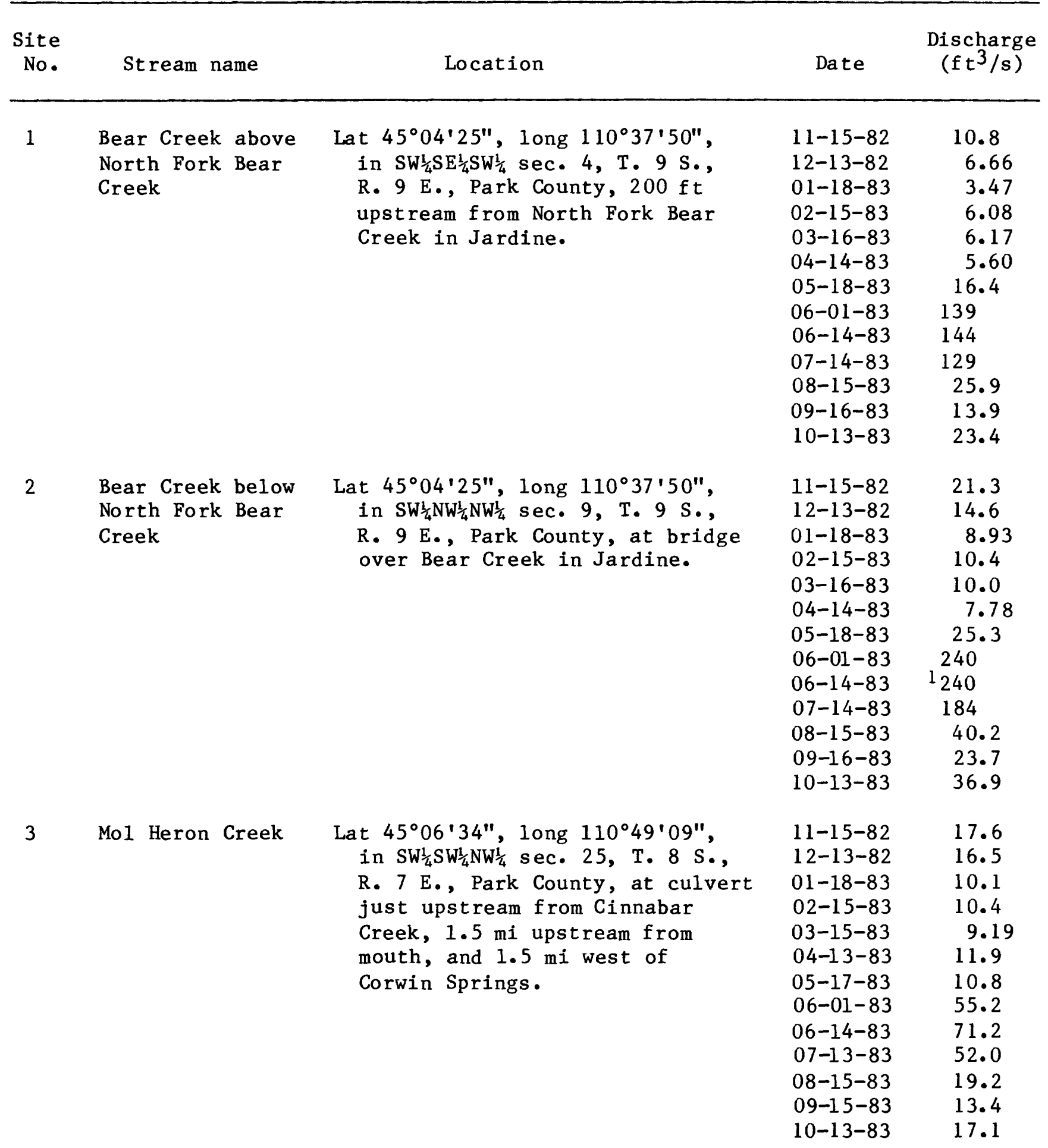




\begin{tabular}{|c|c|c|c|c|}
\hline $\begin{array}{l}\text { Site } \\
\text { No. }\end{array}$ & Stream name & Location & Date & $\begin{array}{c}\text { Discharge } \\
\left(\mathrm{ft}^{3} / \mathrm{s}\right)\end{array}$ \\
\hline 4 & $\begin{array}{l}\text { Cinnabar Creek } \\
\text { above Cotton- } \\
\text { wood Creek }\end{array}$ & 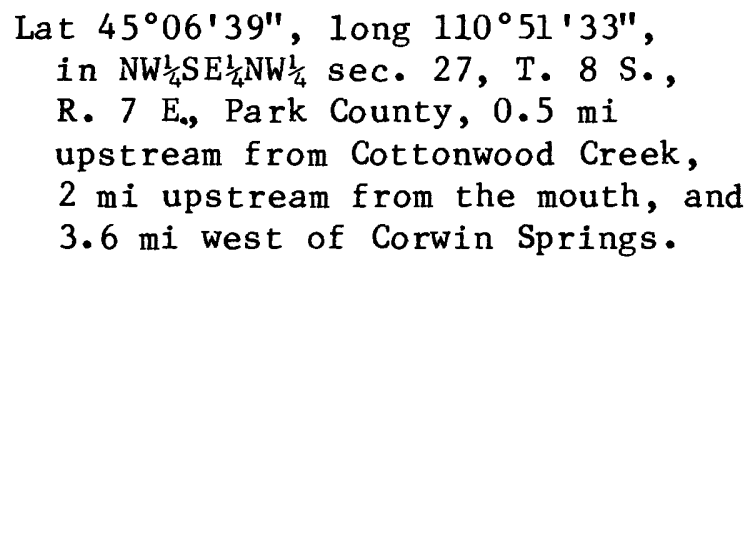 & $\begin{array}{l}11-15-82 \\
12-13-82 \\
01-18-83 \\
02-15-83 \\
03-15-83 \\
04-13-83 \\
05-17-83 \\
06-01-83 \\
06-14-83 \\
07-13-83 \\
08-15-83 \\
09-15-83 \\
10-13-83\end{array}$ & $\begin{array}{c}8.48 \\
6.70 \\
5.27 \\
4.71 \\
5.71 \\
4.99 \\
7.33 \\
29.6 \\
25.0 \\
10.3 \\
10.1 \\
7.35 \\
9.08\end{array}$ \\
\hline 5 & $\begin{array}{l}\text { Cinnabar Creek } \\
\text { at mouth }\end{array}$ & 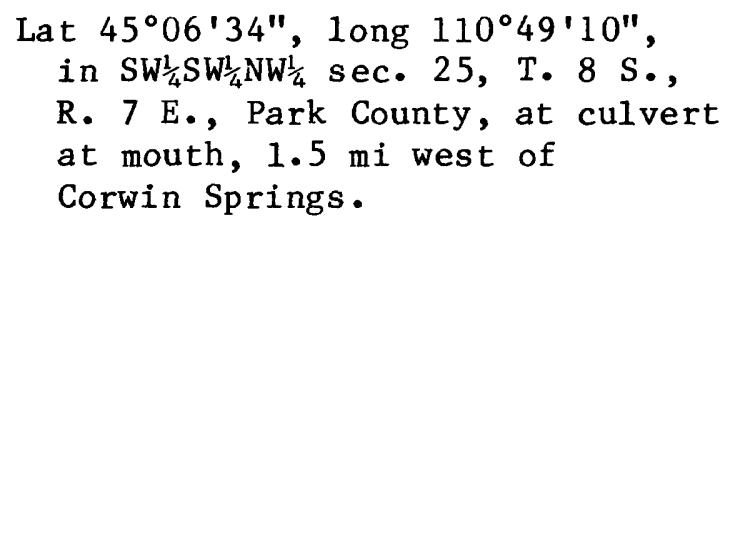 & $\begin{array}{l}11-15-82 \\
12-14-82 \\
01-18-83 \\
02-15-83 \\
03-15-83 \\
04-13-83 \\
05-17-83 \\
06-01-83 \\
06-14-83 \\
07-13-83 \\
08-15-83 \\
09-15-83 \\
10-13-83\end{array}$ & $\begin{array}{c}12.5 \\
7.92 \\
7.01 \\
6.39 \\
7.64 \\
8.00 \\
9.34 \\
28.6 \\
25.7 \\
12.4 \\
12.5 \\
8.25 \\
8.15\end{array}$ \\
\hline 6 & $\begin{array}{l}\text { Mol Heron Creek } \\
\text { below Cinnabar } \\
\text { Creek }\end{array}$ & 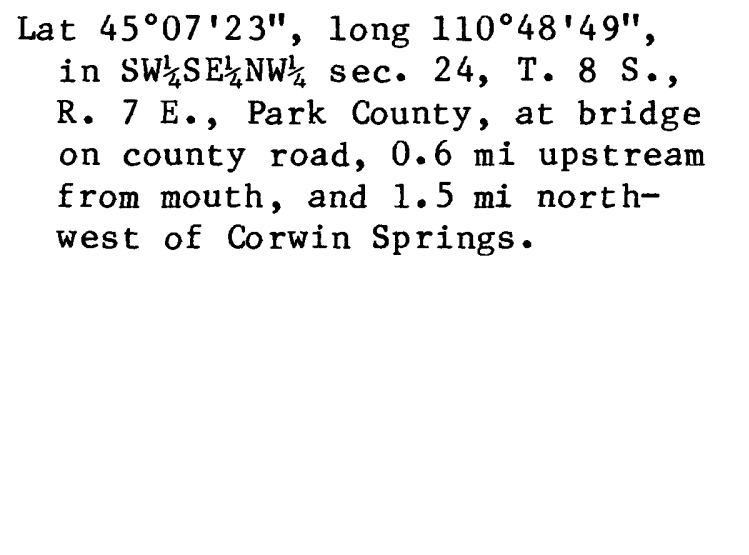 & $\begin{array}{l}11-15-82 \\
12-13-82 \\
01-18-83 \\
02-15-83 \\
03-15-83 \\
04-13-83 \\
05-17-83 \\
06-01-83 \\
06-14-83 \\
07-13-83 \\
08-15-83 \\
09-15-83 \\
10-13-83\end{array}$ & $\begin{array}{l}30.1 \\
24.4 \\
17.1 \\
16.8 \\
16.8 \\
19.9 \\
20.1 \\
83.8 \\
96.9 \\
64.4 \\
31.7 \\
21.7 \\
25.3\end{array}$ \\
\hline
\end{tabular}


Table 11.--Site descriptions and streamflow measurements--Continued

\begin{tabular}{|c|c|c|c|c|}
\hline $\begin{array}{l}\text { Site } \\
\text { No. }\end{array}$ & Stream name & Location & Date & $\begin{array}{l}\text { Discharge } \\
\left(\mathrm{ft}^{3} / \mathrm{s}\right)\end{array}$ \\
\hline 7 & $\begin{array}{l}\text { Cedar Creek at } \\
\text { mouth }\end{array}$ & 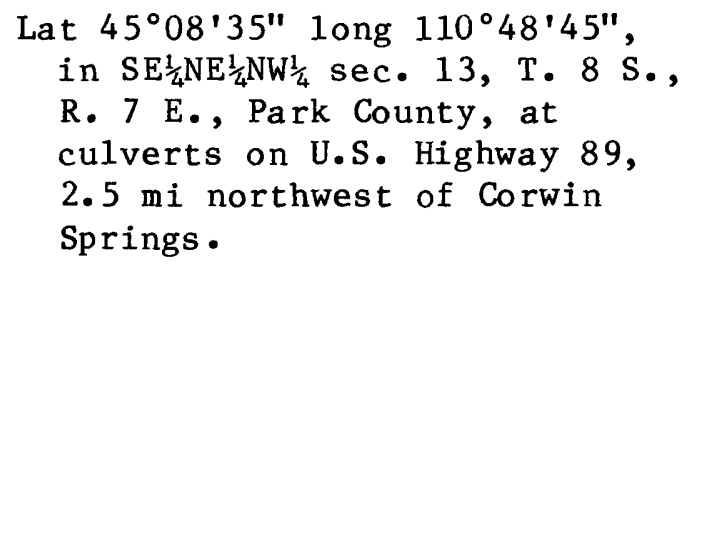 & $\begin{array}{l}11-16-82 \\
12-14-82 \\
01-18-83 \\
02-15-83 \\
03-15-83 \\
04-13-83 \\
05-17-83 \\
06-01-83 \\
06-14-83 \\
07-14-83 \\
08-15-83 \\
09-15-83 \\
10-13-83\end{array}$ & $\begin{array}{c}7.71 \\
6.87 \\
5.74 \\
6.40 \\
5.14 \\
6.34 \\
4.37 \\
17.7 \\
26.3 \\
21.3 \\
1.16 \\
.89 \\
8.09\end{array}$ \\
\hline 8 & $\begin{array}{l}\text { Tom Miner Creek } \\
\text { above Canyon Creek }\end{array}$ & 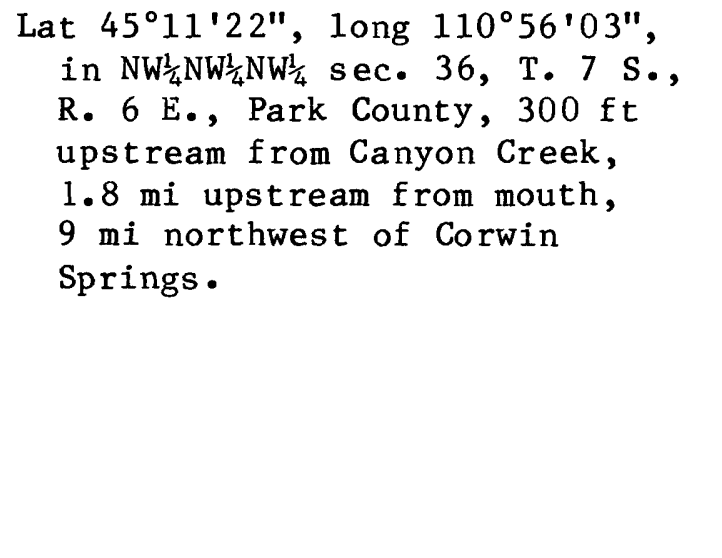 & $\begin{array}{l}11-16-82 \\
12-14-82 \\
01-19-83 \\
02-15-83 \\
03-15-83 \\
04-13-83 \\
05-17-83 \\
06-01-83 \\
06-15-83 \\
07-13-83 \\
08-15-83 \\
09-15-83 \\
10-13-83\end{array}$ & $\begin{array}{c}253.0 \\
28.9 \\
23.5 \\
21.2 \\
29.1 \\
27.1 \\
49.1 \\
168 \\
164 \\
97.2 \\
52.6 \\
30.7 \\
35.0\end{array}$ \\
\hline 9 & $\begin{array}{l}\text { Tom Miner Creek } \\
\text { at mouth }\end{array}$ & 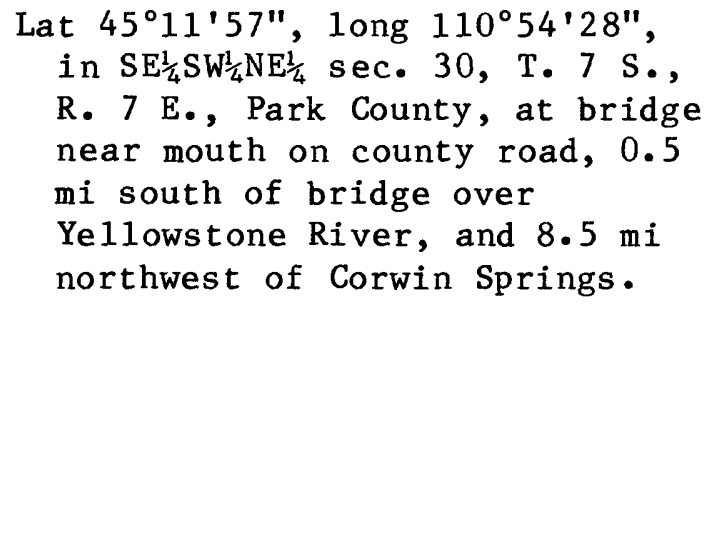 & $\begin{array}{l}11-16-82 \\
12-14-82 \\
01-19-83 \\
02-15-83 \\
03-15-83 \\
04-13-83 \\
05-17-83 \\
06-01-83 \\
06-15-83 \\
07-13-83 \\
08-15-83 \\
09-15-83 \\
10-13-83\end{array}$ & $\begin{array}{c}52.9 \\
35.0 \\
23.2 \\
21.1 \\
29.4 \\
23.9 \\
43.6 \\
165 \\
166 \\
83.8 \\
33.0 \\
21.1 \\
27.9\end{array}$ \\
\hline
\end{tabular}


Table 11.--Site descriptions and streamflow measurements--Continued

$\begin{array}{ccc}\text { Site } & \text { Location } & \text { Discharge } \\ \text { No. } & \text { Dtream name } & \begin{array}{c}\text { Diste } \\ \left(\mathrm{ft}^{3} / \mathrm{s}\right)\end{array}\end{array}$

10 Rock Creek at mouth

11 Sixmile Creek
Lat $45^{\circ} 12 \cdot 39^{\prime \prime}$, long $110^{\circ} 54^{\prime} 11^{\prime \prime}$, in $N E \frac{1}{4} N W \frac{1}{4} S^{\frac{1}{4}}$ sec. 19, T. 7 S., R. 7 E., Park County, at bridge at mouth on county road, 0.4 mi north of bridge over Yellowstone River, and $9 \mathrm{mi}$ northwest of Corwin Springs.

$\begin{array}{cc}11-16-82 & 10.4 \\ 12-14-82 & 7.77 \\ 01-19-83 & 6.91 \\ 02-16-83 & 4.61 \\ 03-15-83 & 6.21 \\ 04-13-83 & 6.64 \\ 05-17-83 & 12.6 \\ 06-01-83 & 123 \\ 06-14-83 & 110 \\ 07-13-83 & 50.9 \\ 08-15-83 & 10.1 \\ 09-15-83 & 4.77 \\ 10-13-83 & 6.52\end{array}$

$11-16-82$

12.5

$12-15-82$

6.06

$01-19-83$

9.33

$02-16-83$

8.19

03-15-83

9.52

$04-13-83$

9.88

$05-17-83$

16.1

$06-01-83$

103

$06-14-83$

138

$07-12-83$

96.8

$08-15-83$

28.0

$09-15-83$

17.8

10-14-83

22.1

Lat $45^{\circ} 21^{\prime} 38^{\prime \prime}$, 1ong $110^{\circ} 47^{\prime} 58^{\prime \prime}$, in $\mathrm{NE}_{\frac{1}{4}} \mathrm{SW}_{\frac{1}{4}} \mathrm{NE}_{\frac{1}{4}} \mathrm{sec}$. 36, T. $5 \mathrm{~S}$., R. 7 E., Park County, just

$11-16-82$

15.4 above Miller Creek upstream from Miller Creek, $21 / 2$ mi upstream from mouth, and $31 / 4 \mathrm{mi}$ west of Emigrant.
$12-15-82$

$01-19-83$

$02-16-83$

6.91

$03-15-83$

12.2

$04-13-83$

9.11

$05-17-83$

15.5

$06-01-83$

56.2

$06-14-83$

$07-13-83$

60.8

29.2

$08-16-83$

10.2

$09-15-83$

9.09

10-13-83

10.8 
Table 11.--Site descriptions and streamflow measurements--Continued

\begin{tabular}{|c|c|c|c|c|}
\hline $\begin{array}{c}\text { Site } \\
\text { No. }\end{array}$ & Stream name & Location & Date & $\begin{array}{c}\text { Discharge } \\
\left(\mathrm{ft}^{3} / \mathrm{s}\right)\end{array}$ \\
\hline 13 & $\begin{array}{l}\text { Fridley Creek at } \\
\text { mouth }\end{array}$ & $\begin{array}{l}\text { Lat } 45^{\circ} 20^{\prime} 43^{\prime \prime}, \text { long } 110^{\circ} 45^{\prime} 23^{\prime \prime} \text {, } \\
\text { in SE } \frac{1}{4} \mathrm{SW}^{\frac{1}{4} \mathrm{NW}} \frac{1}{4} \text { sec. } 4, \mathrm{~T} .6 \mathrm{~S} . \text {, } \\
\text { R. } 8 \mathrm{E} ., \text { Park County, at culvert } \\
\text { on U.S. Highway } 89,2 \mathrm{mi} \\
\text { southwest of Emigrant. }\end{array}$ & $\begin{array}{l}11-16-82 \\
12-15-82 \\
01-19-83 \\
02-16-83 \\
03-15-83 \\
04-13-83 \\
05-17-83 \\
06-01-83 \\
06-14-83 \\
07-13-83 \\
08-16-83 \\
09-15-83 \\
10-13-83\end{array}$ & $\begin{array}{c}3.71 \\
3.60 \\
3.80 \\
2.83 \\
4.88 \\
2.83 \\
2.88 \\
13.7 \\
22.6 \\
19.2 \\
3.82 \\
3.98 \\
3.62\end{array}$ \\
\hline 14 & $\begin{array}{l}\text { Eightmile } \\
\text { Creek near } \\
\text { Emigrant }\end{array}$ & 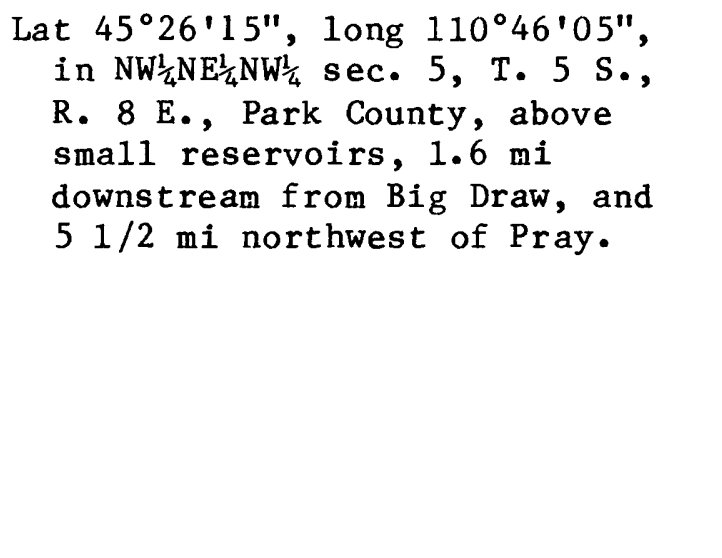 & $\begin{array}{l}11-16-82 \\
12-15-82 \\
01-20-83 \\
02-16-83 \\
03-14-83 \\
04-12-83 \\
05-16-83 \\
05-31-83 \\
06-13-83 \\
07-13-83 \\
08-16-83 \\
09-14-83 \\
10-14-83\end{array}$ & $\begin{array}{c}20.6 \\
8.06 \\
18.8 \\
16.8 \\
20.4 \\
17.4 \\
321.5 \\
338.0 \\
340.0 \\
23.7 \\
20.5 \\
19.7 \\
20.7\end{array}$ \\
\hline 15 & $\begin{array}{l}\text { Mill Creek } \\
\text { above diversions }\end{array}$ & 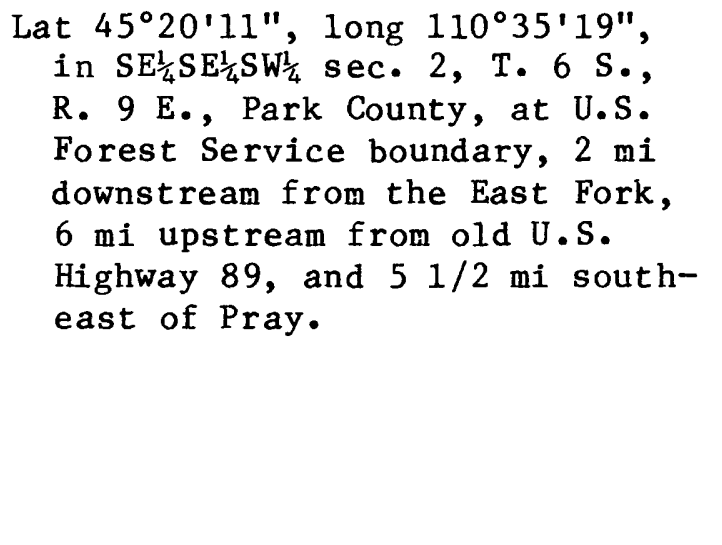 & $\begin{array}{l}11-17-82 \\
12-15-82 \\
01-20-83 \\
02-14-83 \\
03-14-83 \\
04-12-83 \\
05-16-83 \\
05-31-83 \\
06-15-83 \\
07-12-83 \\
08-15-83 \\
09-14-83 \\
10-12-83\end{array}$ & $\begin{array}{c}77.8 \\
23.1 \\
25.8 \\
36.3 \\
48.0 \\
38.0 \\
80.9 \\
567 \\
583 \\
538 \\
111 \\
64.1 \\
89.9\end{array}$ \\
\hline
\end{tabular}


Table 11.--Site descriptions and streamflow measurements--Continued

Site

No.

St ream name

Location

Date

Discharge

16 Trail Creek

Lat $45^{\circ} 29^{\prime} 58^{\prime \prime}$, long $110^{\circ} 42^{\prime} 03^{\prime \prime}$, in $\mathrm{NW} \frac{1}{4} \mathrm{SW} \frac{1}{4} \mathrm{SE} \frac{1}{4} \mathrm{sec} .11, \mathrm{~T} .4 \mathrm{~S}$.,

$11-16-82$

11.7

R. 8 E., Park County, at culvert

$12-15-82$

4.61

on county road, just above Pine

$01-20-83$

6.33

Creek, $13 \mathrm{mi}$ southwest of

$02-16-83$

12.8

Livingston.

03-14-83

16.8

$04-12-83$

11.8

$05-16-83$

27.0

$05-31-83$

62.4

$06-13-83$

50.1

$07-12-83$

23.0

$08-16-83$

10.6

$09-14-83$

8.28

$10-12-83$

7.37

17 Suce Creek

Lat $45^{\circ} 34^{\prime} 01^{\prime \prime}$, long $110^{\circ} 33^{\prime} 30^{\prime \prime}$, in $\mathrm{SW}_{\frac{1}{4}} \mathrm{NW}_{\frac{1}{4}} \mathrm{NE}_{\frac{1}{4}} \mathrm{sec} .24, \mathrm{~T}$. $3 \mathrm{~S}$.,

$11-17-82$

1.78

R. 9 E., Park County, at bridge

$12-16-82$

.84

on old U.S. Highway 89, 1 mi up-

$01-17-83$

1.04

stream from mouth, and $61 / 2 \mathrm{mi}$

$02-14-83$

south of Livingston.

$03-14-83$

2.79

$04-12-83$

1.97

$05-16-83$

3.03

$05-31-83$

37.2

$06-13-83$

39.2

$07-12-83$

8.41

08-16-83

5.30

$09-14-83$

3.41

10-12-83

1.56

18

Billman Creek

Lat $45^{\circ} 39^{\prime} 30^{\prime \prime}$, long $110^{\circ} 39^{\prime} 04^{\prime \prime}$,
in NW/ $\mathrm{SW}_{\frac{1}{4}} \mathrm{SW} \frac{1}{4} \mathrm{sec} .17, \mathrm{~T} .2 \mathrm{~S} .$,
R. $9 \mathrm{E} .$, Park County, at
concrete bridge, $0.1 \mathrm{mi}$ upstream
from Miner Creek, $0.15 \mathrm{mi}$ south
of frontage road, and $41 / 2$
mi west of Livingston.

$11-17-82$

3.29

$12-16-82$

3.62

$01-17-83$

3.60

$02-14-83$

3.65

$03-14-83$

8.51

04-12-83

8.87

$05-16-83$

24.8

05-31-83 24.1

$06-13-83$

$07-12-83$

08-16-83

$09-14-83$

13.6

8.47

4.05

2.89

10-12-83

2.40 
Table 11.--Site descriptions and streamflow measurements--Continued

\begin{tabular}{|c|c|c|c|c|}
\hline $\begin{array}{l}\text { Site } \\
\text { No. }\end{array}$ & Stream name & Location & Date & $\begin{array}{c}\text { Discharge } \\
\left(\mathrm{ft}^{3} / \mathrm{s}\right)\end{array}$ \\
\hline 19 & Miner Creek & 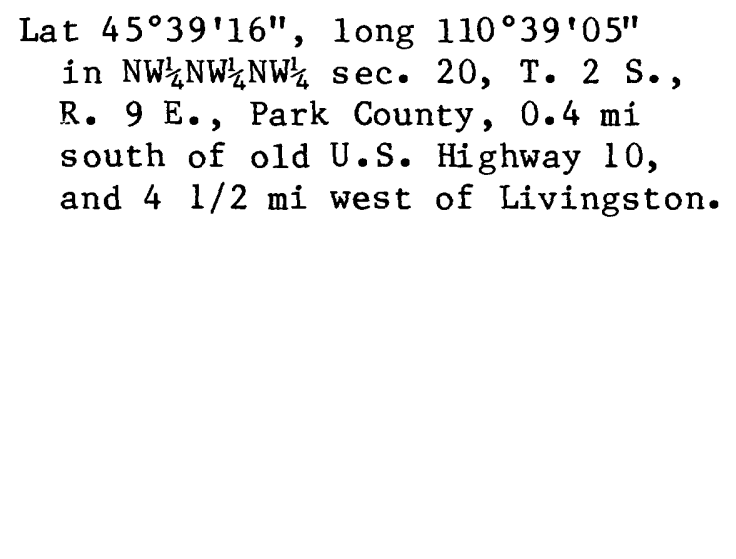 & $\begin{array}{l}11-17-82 \\
12-16-82 \\
01-17-83 \\
02-14-83 \\
03-14-83 \\
04-12-83 \\
05-16-83 \\
05-31-83 \\
06-13-83 \\
07-12-83 \\
08-16-83 \\
09-14-83 \\
10-12-83\end{array}$ & $\begin{array}{c}2.16 \\
3.41 \\
2.52 \\
2.01 \\
8.99 \\
4.84 \\
20.6 \\
15.6 \\
8.97 \\
4.44 \\
1.99 \\
1.66 \\
1.85\end{array}$ \\
\hline 20 & $\begin{array}{l}\text { Billman Creek } \\
\text { at mouth }\end{array}$ & 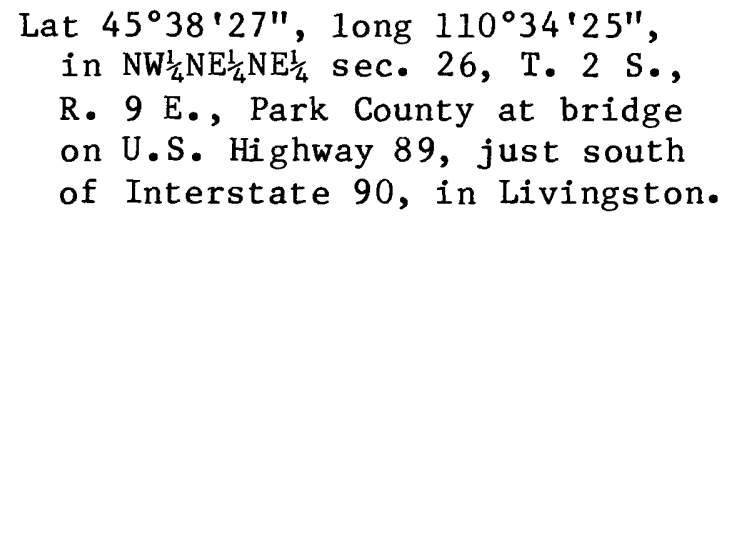 & $\begin{array}{l}11-17-82 \\
12-16-82 \\
01-17-83 \\
02-14-83 \\
03-14-83 \\
04-12-83 \\
05-16-83 \\
05-31-83 \\
06-13-83 \\
07-12-83 \\
08-16-83 \\
09-14-83 \\
10-12-83\end{array}$ & $\begin{array}{c}6.48 \\
2.44 \\
4.69 \\
5.35 \\
18.0 \\
13.8 \\
44.6 \\
39.1 \\
17.8 \\
12.1 \\
2.48 \\
1.80 \\
4.19\end{array}$ \\
\hline 21 & $\begin{array}{l}\text { Fleshman Creek } \\
\text { at mouth }\end{array}$ & 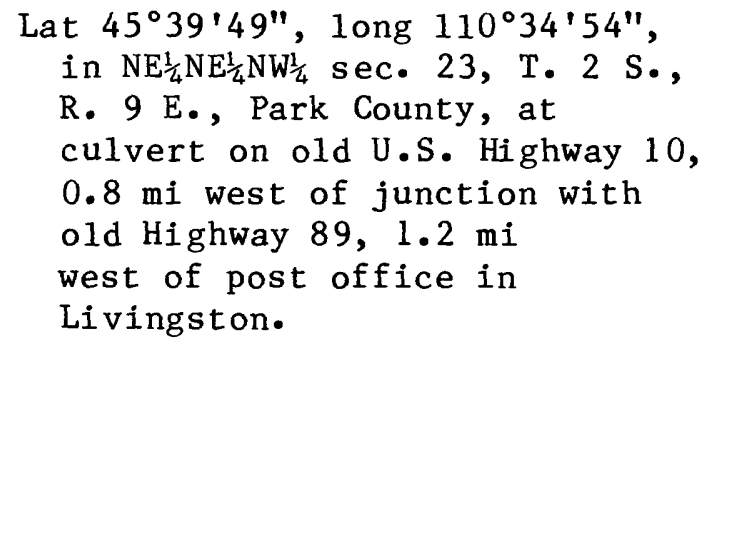 & $\begin{array}{l}11-15-82 \\
12-16-82 \\
01-17-83 \\
02-14-83 \\
03-14-83 \\
04-12-83 \\
05-16-83 \\
05-31-83 \\
06-13-83 \\
07-12-83 \\
08-16-83 \\
09-14-83 \\
10-12-83\end{array}$ & $\begin{array}{c}3.93 \\
3.48 \\
2.44 \\
2.27 \\
3.72 \\
4.17 \\
13.0 \\
6.77 \\
2.44 \\
3.31 \\
1.10 \\
.85 \\
1.35\end{array}$ \\
\hline
\end{tabular}


Table 11.--Site descriptions and streamflow measurements--Continued

\begin{tabular}{ccc}
\hline $\begin{array}{c}\text { Site } \\
\text { No. }\end{array}$ Stream name & Location & $\begin{array}{c}\text { Discharge } \\
\left(\mathrm{ft}^{3} / \mathrm{s}^{3}\right.\end{array}$ \\
\hline
\end{tabular}

22 Smith Creek

Lat $46^{\circ} 10^{\prime} 34^{\prime \prime}$, long $110^{\circ} 32^{\prime} 13^{\prime \prime}$,

$10-12-83$

5.23

in $\mathrm{NW}_{\frac{1}{4}} \mathrm{NE}_{\frac{1}{4}} \mathrm{SE}_{\frac{1}{4}}$ sec. $24, \mathrm{~T} .5 \mathrm{~N}$.,

$11-16-83$

8.23

R. 9 E., Park County, at private

$12-13-83$

3.66

bridge $0.1 \mathrm{mi}$ above Meadow

$01-10-84$

4.86

Creek, and $14 \mathrm{mi}$ northeast of

3.61

Wilsall.

$02-14-84$

2.78

$03-13-84$

19.7

$04-16-84$

160

$05-14-84$

$06-12-84$

59.8

$07-16-84$

10.3

$08-14-84$

7.96

$09-12-84$

5.10

23 Flathead Creek above Cache Creek
Lat $45^{\circ} 58^{\prime} 37^{\prime \prime}$, long $110^{\circ} 50^{\prime} 12^{\prime \prime}$,
in $N W \frac{1}{4} \mathrm{SE}_{\frac{1}{4}} \mathrm{SE}_{\frac{1}{4}} \mathrm{sec} .27, \mathrm{~T} .3 \mathrm{~N}$.,
R. 7 E., Park County, at bridge
on county road, $1.3 \mathrm{mi}$ north
of old town of Sedan, and $81 / 2$
mi west of Wilsall.

10-12-83

6.54

$11-16-83$

7.62

$12-13-83$

7.10

$01-10-84$

$02-14-84$

11.8

$03-13-84$

7.60

04-16-84

5.86

05-14-84

23.6

$06-12-84$

55.8

$07-16-84$

26.2

$08-14-84$

11.7

09-12-84

5.84

5.16

$24 \quad$ Flathead Creek

Lat $45^{\circ} 59^{\prime} 31^{\prime \prime}$, long $110^{\circ} 42^{\prime} 26^{\prime \prime}$,

10-12-83

23.2

above Muddy

Creek

in $\mathrm{NW}_{\frac{1}{4}} \mathrm{SW} \frac{1}{4} \mathrm{SW} \frac{1}{4}$ sec. 23, T. 3 N.,

$11-16-83$

36.0

R. 8 E., Park County, at old

$12-13-83$

18.2

bridge crossing, $0.1 \mathrm{mi}$ south of

01-10-84

29.2

Flathead Road, and $2.3 \mathrm{mi}$ west

02-14-84

20.6

of Wilsall.

03-13-84

18.5

04-16-84

05-14-84

66.0

$06-12-84$

148

$07-16-84$

80.0

$08-14-84$

26.1

09-12-84

8.88

23.8 
Table 11.--Site descriptions and streamflow measurements--Continued

Site

No.

St ream name

Location

Date

Discharge

$\left(\mathrm{ft}^{3 / \mathrm{s}}\right)$

$25 \quad$ Flathead Creek at mouth

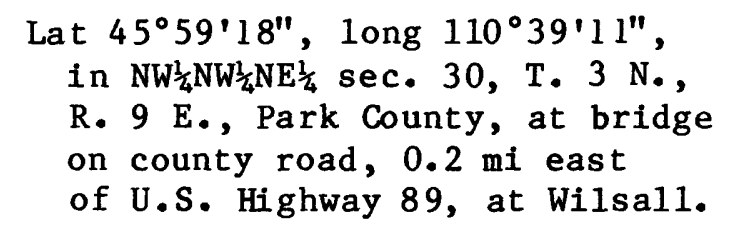

11-16-83

40.0

12-13-83

22.8

01-10-84

50.6

02-14-84 29.2

03-13-84 48.1

04-16-84 84.4

05-15-84 181

06-12-84 56.4

07-16-84 34.9

08-14-84

1.65

09-12-84

2.89

10-15-84

19.5

26 Cottonwood Creek above S1ippery Creek

Lat $45^{\circ} 59^{\prime} 17^{\prime \prime}$, long $110^{\circ} 25^{\prime} 4^{\prime \prime}$,

10-12-83

19.5

in $\mathrm{SW}_{\frac{1}{4}} \mathrm{SE}_{\frac{1}{4}} \mathrm{SW}_{\frac{1}{4}} \mathrm{sec} .24, \mathrm{~T} .3 \mathrm{~N}$.,

$11-16-83$

R. $10 \mathrm{E} .$, Park County, $0.5 \mathrm{mi}$

$12-13-83$

13.9

upstream from S1ippery Creek,

$01-10-84$

29.20

$1.3 \mathrm{mi}$ upstream from U.S. Forest

02-14-84

29.06

Service boundary, and $11 \mathrm{mi}$

03-13-84

28.32

northeast of $\mathrm{Clyde}$ Park.

04-16-84

8.32

$05-14-84$

215.7

$06-12-84$

72.0

07-16-84

97.0

$08-14-84$

63.7

09-12-84

20.6

12.7

27 Cottonwood Creek below Little Cottonwood Creek

Lat $45^{\circ} 57^{\prime} 01^{\prime \prime}$, long $110^{\circ} 27^{\prime} 10^{\prime \prime}$,

$\begin{array}{cc}10-12-83 & 17.3 \\ 11-16-83 & 18.1 \\ 12-13-83 & 15.9 \\ 01-10-84 & 12.2 \\ 02-14-84 & 10.7 \\ 03-13-84 & 9.62 \\ 04-16-84 & 20.1 \\ 05-14-84 & 125 \\ 06-12-84 & 71.6 \\ 07-16-84 & 42.2 \\ 08-14-84 & 23.5 \\ 09-12-84 & 23.5\end{array}$

in $\mathrm{NE}_{\frac{1}{4}} \mathrm{NW}_{\frac{1}{4}} \mathrm{SW}_{\frac{1}{4}}$ sec. 2 , T. $2 \mathrm{~N}$., R. 10 E., Park County, at bridge on county road, $81 / 2$ mi northeast of Clyde Park.

09-12-84

23.5 


\begin{tabular}{|c|c|c|c|c|}
\hline $\begin{array}{l}\text { Site } \\
\text { No. }\end{array}$ & Stream name & Location & Date & $\begin{array}{c}\text { Discharge } \\
\left(\mathrm{ft}^{3} / \mathrm{s}\right)\end{array}$ \\
\hline 28 & $\begin{array}{l}\text { North Fork } \\
\text { Brackett Creek }\end{array}$ & 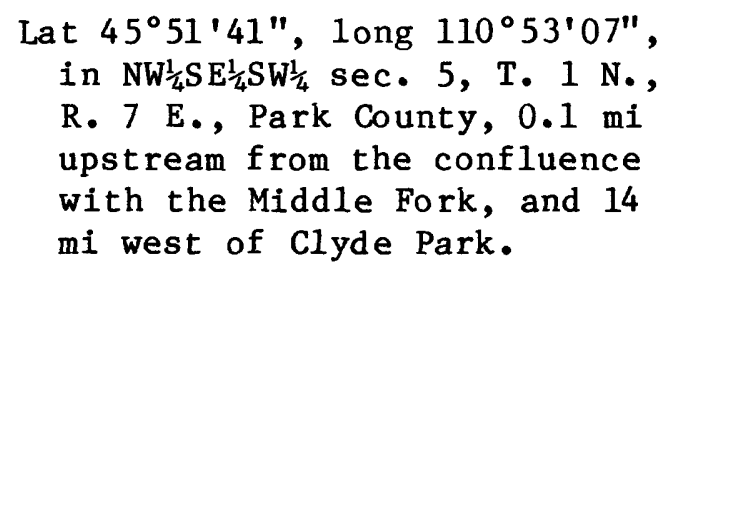 & $\begin{array}{l}10-13-83 \\
11-18-83 \\
12-14-83 \\
01-11-84 \\
02-15-84 \\
03-13-84 \\
04-16-84 \\
05-15-84 \\
06-13-84 \\
07-17-84 \\
08-15-84 \\
09-13-84\end{array}$ & $\begin{array}{c}3.82 \\
5.03 \\
3.22 \\
4.47 \\
2.76 \\
2.42 \\
15.9 \\
72.3 \\
33.8 \\
9.98 \\
4.57 \\
3.00\end{array}$ \\
\hline 29 & $\begin{array}{l}\text { Middle Fork } \\
\text { Brackett Creek }\end{array}$ & 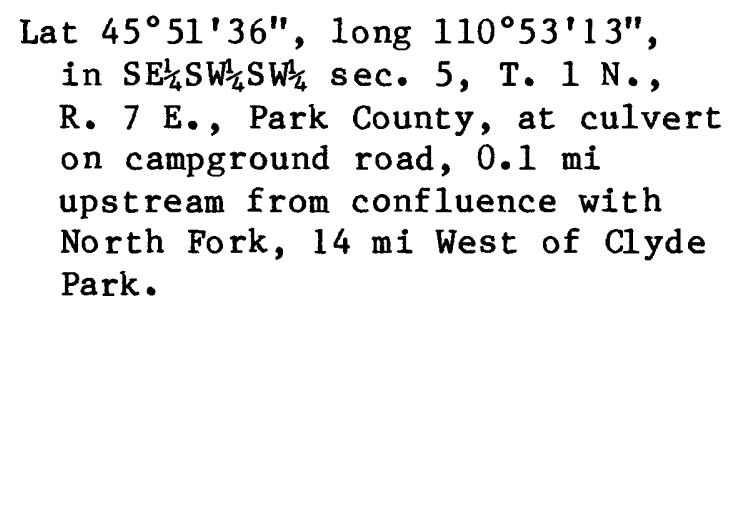 & $\begin{array}{l}10-13-83 \\
11-18-83 \\
12-14-83 \\
01-11-84 \\
02-15-84 \\
03-13-84 \\
04-16-84 \\
05-15-84 \\
06-13-84 \\
07-17-84 \\
08-15-84 \\
09-13-84\end{array}$ & $\begin{array}{c}2.31 \\
3.55 \\
2.14 \\
2.89 \\
1.12 \\
1.57 \\
16.7 \\
51.7 \\
32.0 \\
4.18 \\
1.88 \\
1.37\end{array}$ \\
\hline 30 & $\begin{array}{l}\text { South Fork } \\
\text { Brackett Creek }\end{array}$ & 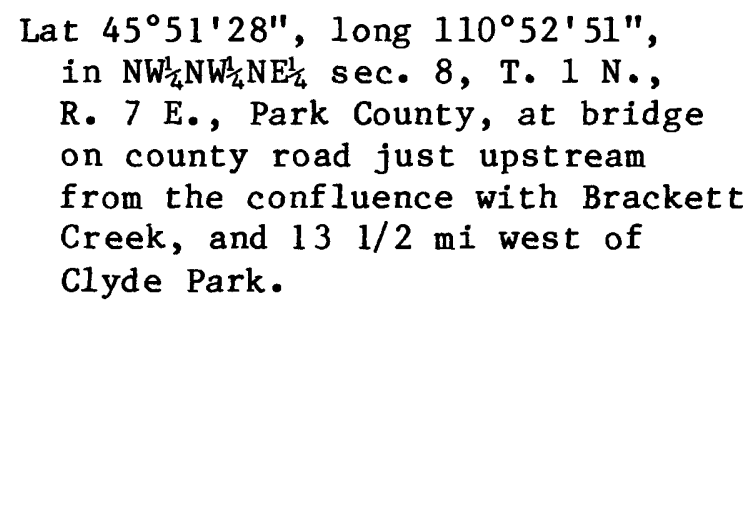 & $\begin{array}{l}10-13-83 \\
11-18-83 \\
12-14-83 \\
01-10-84 \\
02-14-84 \\
03-13-84 \\
04-16-84 \\
05-15-84 \\
06-12-84 \\
07-17-84 \\
08-15-84 \\
09-12-84\end{array}$ & $\begin{array}{c}1.72 \\
2.34 \\
1.83 \\
2.59 \\
1.12 \\
1.00 \\
14.8 \\
34.0 \\
23.9 \\
5.14 \\
2.21 \\
1.68\end{array}$ \\
\hline
\end{tabular}


Table 11.--Site descriptions and streamflow measurements--Continued

Site

No.

St ream name

Location

Date

Discharge

$\left(\mathrm{ft}^{3} / \mathrm{s}\right)$

31 Brackett

Creek above

Weasel Creek

32 Brackett Creek above Fox Creek

33 Brackett Creek near Clyde Park (discontinued gaged site 06194000)
Lat $45^{\circ} 51^{\prime} 42^{\prime \prime}$, long $110^{\circ} 50^{\prime} 17^{\prime \prime}$, in $\mathrm{NW}_{\frac{1}{4}} \mathrm{SW}_{\frac{1}{4}}^{\frac{1}{4}} \mathrm{SE} \frac{1}{4} \mathrm{sec} .3, \mathrm{~T} .1 \mathrm{~N}$., R. 7 E., Park County, at U.S. Forest Service bridge upstream from Weasel Creek, 11 1/2 mi west of Clyde Park.

$\begin{array}{cc}10-13-83 & 7.53 \\ 11-18-83 & 10.6 \\ 12-13-83 & 7.19 \\ 01-11-84 & 9.95 \\ 02-14-84 & 5.00 \\ 03-13-84 & 4.99 \\ 04-16-84 & 47.4 \\ 05-15-84 & 158 \\ 06-13-84 & 89.7 \\ 07-17-84 & 19.6 \\ 08-15-84 & 8.21 \\ 09-12-84 & 6.56\end{array}$

Lat $45^{\circ} 52^{\prime} 24^{\prime \prime}$, long $110^{\circ} 43^{\prime} 27^{\prime \prime}$, in $N W_{\frac{1}{4}} \mathrm{NW}_{\frac{1}{4}} \mathrm{NW} \frac{1}{4} \mathrm{sec}$. 3, T. $1 \mathrm{~N}$., R. 8 E., Park County, at bridge

10-12-83

$11-18-83$

$12-13-83$

$01-10-84$

$02-14-84$

$03-13-84$

$04-16-84$

05-14-84

$06-12-84$

$07-17-84$

08-14-84

09-12-84

10-12-83

$11-18-83$

12-13-83

01-10-84

02-14-84

03-13-84

04-16-84

05-14-84

06-12-84

07-16-84

08-14-84

09-12-84
12.8

12.2

12.5

25.9

10.9

9.51

44.1

223

127

13.3

11.8

15.1

17.5

16.0

26.9

14.0

11.0

51.5

216

138

21.8

13.7

12.3
23.4 
Table 11.--Site descriptions and streamflow measurements--Continued

Site

No.

St ream name

Location

Date

Discharge

$\left(f t^{3} / s\right)$

37 Mission Creek

below Little

Mission Creek

near Livingston

38 Upper Deer Creek Lat $45^{\circ} 42^{\prime} 08^{\prime \prime}$, long $109^{\circ} 55^{\prime} 59^{\prime \prime}$, in $\mathrm{SW}_{\frac{1}{4}} \mathrm{NE} \frac{1}{4} \mathrm{SE} \frac{1}{4}$ sec. 36 , T. $1 \mathrm{~S}$., R. 14 E., Sweet Grass County, at private crossing on creek, $0.2 \mathrm{mi}$ downstream from the west fork, and $81 / 2 \mathrm{mi}$ southwest of Greycliff.

in $\mathrm{NE}_{\frac{1}{4}} \mathrm{NE}_{\frac{1}{4}} \mathrm{NW}_{\frac{1}{4}}$ sec. 33 , T. 2 S., R. 11 E., Park County, downstream from Little Mission Creek, $81 / 2 \mathrm{mi}$ southeast of Livingston.

$\begin{array}{lll}10-14-83 & 4 & 12.2 \\ 11-17-83 & 4 & 15.1 \\ 12-15-83 & 4 & 8.76 \\ 01-12-84 & 4 & 12.5 \\ 02-14-84 & 4 & 8.44 \\ 03-14-84 & 4 & 9.48 \\ 04-18-84 & 4 & 34.8 \\ 05-16-84 & 4 & 257 \\ 06-13-84 & 4 & 77.7 \\ 07-17-84 & 4 & 42.2 \\ 08-15-84 & 4 & 16.2 \\ 09-13-84 & 4 & 14.9\end{array}$

$10-13-83$

$11-17-83$

$12-14-83$

01-11-84

02-15-84

03-14-84

04-17-84

05-15-84

06-13-84

07-17-84

08-15-84

09-13-84

7.52

7.82

24.98

211.4

5.59

7.09

36.7

344

61.2

10.3

4.90

4.29

10-13-83

7.29

11-17-83

7.12

in $\mathrm{SW}_{\frac{1}{4}} \mathrm{SW}_{\frac{1}{4}} \mathrm{SE}_{\frac{1}{4}}$ sec. 4, T. 2 S.,

$12-14-83$

5.81

at private bridge crossing

$01-11-84$

12.0

just upstream from Log Cabin

02-15-84

5.88

Creek, $7 \mathrm{mi}$ southwest of

03-14-84

7.80

Greycliff.

04-17-84

19.9

05-15-84 238

06-13-84 70.7

$07-17-84 \quad 20.3$

08-15-84

9.10

09-13-84

7.54 
Table 11.--Site descriptions and streamflow measurements--Continued

\begin{tabular}{|c|c|c|c|c|}
\hline $\begin{array}{c}\text { Site } \\
\text { No. }\end{array}$ & Stream name & Location & Date & $\begin{array}{c}\text { Discharge } \\
\left(\mathrm{f} \mathrm{t}^{3} / \mathrm{s}\right)\end{array}$ \\
\hline 40 & Bridger Creek & 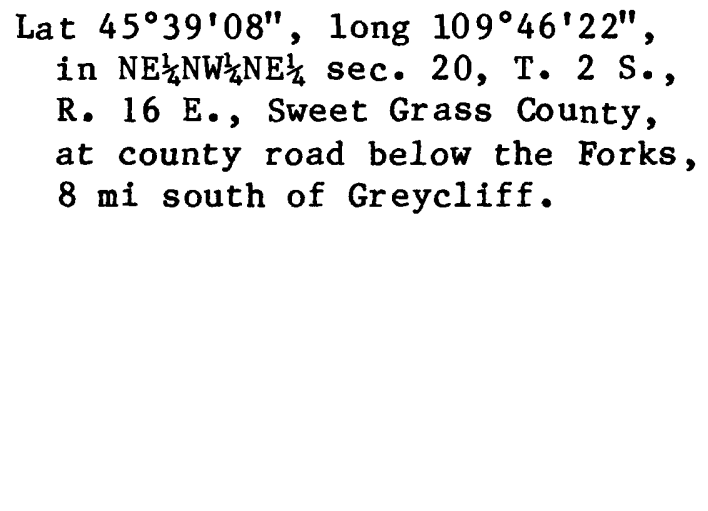 & $\begin{array}{l}10-13-83 \\
11-17-83 \\
12-14-83 \\
01-11-84 \\
02-15-84 \\
03-14-84 \\
04-17-84 \\
05-15-84 \\
06-13-84 \\
07-17-84 \\
08-15-84 \\
09-13-84\end{array}$ & $\begin{array}{c}2.88 \\
2.52 \\
2.20 \\
4.71 \\
5.65 \\
4.19 \\
10.9 \\
122 \\
18.6 \\
4.69 \\
2.70 \\
2.08\end{array}$ \\
\hline
\end{tabular}

Discharge determined from rating table.

2 Estimated.

3 Partly estimated.

4 Discharge obtained by adding discharge at sites 35 and 36 . 